\title{
The Grandest Challenge of All: The Role of Environmental Engineering to Achieve Sustainability in the World's Developing Regions
}

\author{
James R. Mihelcic, ${ }^{1, *, \dagger}$ Colleen C. Naughton, Matthew E. Verbyla, Qiong Zhang, ${ }^{1, \dagger}$ \\ Ryan W. Schweitzer, ${ }^{2}$ Stewart M. Oakley, E. Christian Wells, and Linda M. Whiteford ${ }^{4}$ \\ ${ }^{1}$ Department of Civil \& Environmental Engineering, University of South Florida, Tampa, Florida. \\ ${ }^{2}$ Aguaconsult Ltd., Wivenhoe, Essex, United Kingdom. \\ ${ }^{3}$ Department of Civil Engineering, California State University, Chico, California. \\ ${ }^{4}$ Department of Anthropology, University of South Florida, Tampa, Florida.
}

Received: August 28, 2015

Accepted in revised form: May 6, 2016

\begin{abstract}
The environmental engineering discipline has focused much of its historical efforts in developing regions of the world on advancing environmental sustainability through improving provision of water, sanitation, and hygiene (WASH) services. However, the skills and expertise that reside within the discipline of environmental engineering are fundamental to achieve a much broader range of sustainable development goals, including those related to health, climate, water, energy, and food security; economic development; and reduction of social inequalities. Accordingly, this article critically reviews several focus areas where environmental engineering should assume a more active presence in the global community that seeks to achieve sustainability in developing regions of the world. The 10 environmental engineering Grand Challenges for the developing world covered are: (1) understand the historical perspective of the discipline's connection with public health as the field transitions forward; (2) integrate the differences encountered when operating over rural to urban locations; (3) address emissions of greenhouse gases and other important carbon-containing pollutants; (4) understand the link between development and health to better connect health outcomes and reduction in risk with ecosystem management and other development interventions; (5) address the complex interactions of water energy systems; (6) integrate the synergy inherent in development/ sustainability goals of WASH, food security, and resource recovery; (7) transition to a green economy; (8) advance monitoring, evaluation, and assessment activities that include life cycle assessment, (9) integrate culture, perception, and behavior with advances in science and technology, and (10) educate globally competent engineers. Our hope is that this discussion leads to a better world through monumental improvements in the environment and human well-being and drives new innovations and opportunities in research, education, practice, and service.
\end{abstract}

Key words: environment; global competency; greenhouse gas; hygiene; sanitation; sustainable development; water

\section{Introduction}

A S The WORld POPUlation and economy have grown, A environmental pressure has increased, and many of the world's major ecosystem goods and services have been degraded or used unsustainably (Millennium Ecosystem

*Corresponding author: Department of Civil \& Environmental Engineering, University of South Florida, 4202 E. Fowler Avenue, ENB 118, Tampa, FL 33620. Phone: 813-974-9896; Fax: 813-9742957; E-mail: jm41@usf.edu

${ }^{\dagger}$ Member of AEESP.

(C) James R. Mihelcic et al. 2017; Published by Mary Ann Liebert, Inc. This is an Open Access article distributed under the terms of the Creative Commons Attribution License, which permits unrestricted use, distribution, and reproduction in any medium, provided the original work is properly cited. Mary Ann Liebert, Inc. offers reprint services for those who want to order professionally produced copies of articles published under the Creative Commons Attribution (CC BY) license. To obtain a price quote, email Reprints@liebertpub.com. Please include the article's title or DOI, quantity, and delivery destination in your email.
Assessment, 2005). In developing regions of the world, ${ }^{\mathrm{a}}$ the

${ }^{\mathrm{a}}$ The United Nations reports there is no established convention for designating developed and developing countries or areas. However, it is common practice that Japan in Asia, Canada and the United States in North America, Australia and New Zealand in Oceania, and Europe are considered developed regions or areas. Developing countries typically have a low standard of living and low human development index (United Nations). The International Monetary Fund (IMF) separates countries by advanced economies, countries in transition, and developing countries. Advanced economies typically have per capita GDP $>$ \$U.S. 15,000. The IMF currently lists 126 developing countries, which include Brazil, China, and India. 
link between the environment and economic and social wellbeing is particularly strong. For example, an estimated $24 \%$ of global disease burden is attributed to environmental factors, and for children under 14 years, this burden is as high as $36 \%$ (Prüss-Üstün and Corvalán, 2006). In addition, the global population living in poverty makes extensive use of goods and services provided from a common pool of terrestrial and aquatic natural resources. Natural resources are also known to support an important social safety net during times of economic downturn and constrained food supplies (WRI, 2005).

There is strong synergy between discipline expertise found in the field of environmental engineering and global efforts to ensure prosperity in developing regions. For example, the eight Millennium Development Goals (MDGs) guided international development efforts for the past decade and a half. Environmental engineering had identified most closely with MDG 7-ensuring environmental sustainability and especially topics related to water and health.

Accordingly, many environmental engineers have focused efforts in developing regions on the provision and study of water, sanitation, and hygiene (WASH) services that include (1) identifying environmental and governance barriers to achieve sanitation coverage (Fry et al., 2008), (2) determining costs to meet global coverage for safe water and sanitation (Hutton and Bartram, 2008), (3) assessing factors that lead to changes in hand washing behavior (Naughton et al., 2015a), (4) assessing water quality during household water transport (Harris et al., 2013), household water storage (Schafer and Mihelcic, 2012), and self-supply groundwater systems (Akers et al., 2015), (5) improving our understanding of the design and operation of conventional and resource recovery-based sanitation systems (Mehl et al., 2011; Verbyla et al., 2013a; Exley et al., 2015), and (6) improving the design and management of hand pumps and point-of-use treatment technologies (Clasen et al., 2004; Schweitzer et al., 2013; Marks et al., 2014).

Research has also addressed quantifying global use of solid fuels (Rehfuess et al., 2006), related biodiversity conservation to poverty (Adams et al., 2004), and covered broader issues such as estimating the economic requirements to finance the MDGs (Lee et al., 2004), reviewing the role of nanotechnology in meeting the MDGs (Salamanca-Buentello et al., 2005), and discussing how to meet the MDGs in urban environments (Hasan et al., 2005). There is also much research that interconnects health and MDGs (Acharya, 2007; Fry et al., 2013).

Great progress has been made toward achieving MDGs; in fact, 147 countries have met the 2015 target for access to improved water and 77 countries have met the 2015 target for improved sanitation (UN, 2015). Unfortunately, 663 million people still live without improved water, 2.4 billion do not have improved sanitation, 946 million practice open defecation (UN, 2015), and 1.5 billion use sewer collection systems without treatment (Baum et al., 2013). Furthermore, the disease burden associated with lack of WASH services is still high, with estimates of 502,000 diarrhea deaths due to inadequate drinking water, 280,000 diarrhea deaths from lack of sanitation, and 297,000 diarrhea deaths from lack of hand hygiene (Prüss-Ustün et al., 2014). Moreover, outdoor air pollution annually causes 3.7 million premature deaths and indoor air pollution results in 4.3 million premature deaths (WHO, 2015).
On September 25, 2015, the United Nations General Assembly unanimously adopted an agenda to pursue a sustainable future by 2030, thus replacing MDGs with Sustainable Development Goals (SDGs) (UN, 2016). The SDGs include 17 goals and 169 targets, and while environmental engineering is linked to all goals, the following three goals are examples that can drive innovation and research in the discipline: (1) Goal 6: Ensure availability and sustainable management of water and sanitation for all, (2) Goal 11: Make cities and human settlements inclusive, safe, resilient, and sustainable, and (3) Goal 13: Take urgent action to combat climate change and its impacts (UN, 2016).

As was stated previously, until now, environmental engineers have focused most efforts in the developing regions on improving environmental sustainability. However, the skills and expertise that reside within the environmental engineering community are fundamental to achieve a much broader range of SDGs, including those related to health; water, energy, and food security; economic development; and reduction of poverty and social inequalities.

One factor that must be considered when addressing environmental engineering challenges is the issue of an increasingly affluent and global population, which has now exceeded 7.2 billion; 53\% who live in urban settings (Population Reference Bureau, 2014). Of this total, $\sim 6$ billion live in developing regions $(\sim 4.6$ billion with exclusion of China) (Population Reference Bureau, 2014). Future population growth is expected to be concentrated in less developed regions; in fact, 48 countries with the lowest incomes and highest vulnerability are experiencing population increases of $2.4 \%$ per year (Population Reference Bureau, 2014).

Environmental engineering has always played a critical role to assure environmental sustainability. However, today's environmental challenges are increasingly subtle and complex and solutions must now consider global change (Anastas, 2012). Environmental engineering must continue to adapt to current and future grand challenges and work with existing and new partner disciplines. Staying connected to the historical origins of environmental engineering can help provide perspective through this transition. Accordingly, the goal of this review is to critically examine the many roles that the environmental engineering discipline can and should be playing as we seek to achieve sustainability in developing regions of the world. Our hope is that this discussion will drive new innovations and opportunities in research, education, practice, and service that support the emerging post2015 development agenda (including the SDGs) and lead to a better world through monumental improvements in the environment and human well-being.

The 10 environmental engineering Grand Challenges to achieve sustainability in the world's developing regions are shown in Fig. 1. They can be briefly summarized as follows: (1) understand the historical perspective of the discipline's connection with public health as the field transitions forward; (2) integrate the differences encountered when operating over rural to urban locations; (3) address emissions of greenhouse gases (GHGs) and other important carbon-containing pollutants; (4) understand the link between development and health to better connect health outcomes and reduction in risk with ecosystem management and other development interventions; (5) address the complex interactions of waterenergy systems; (6) integrate the synergy inherent in 
FIG. 1. The 10 environmental engineering Grand Challenges to achieve sustainability in the world's developing regions that integrate the United Nations Sustainable Development Goals (UN, 2016) and other environmental issues and challenges (NAE, 2004; Mo and Rheingans, 2006; UNEP, 2014a).

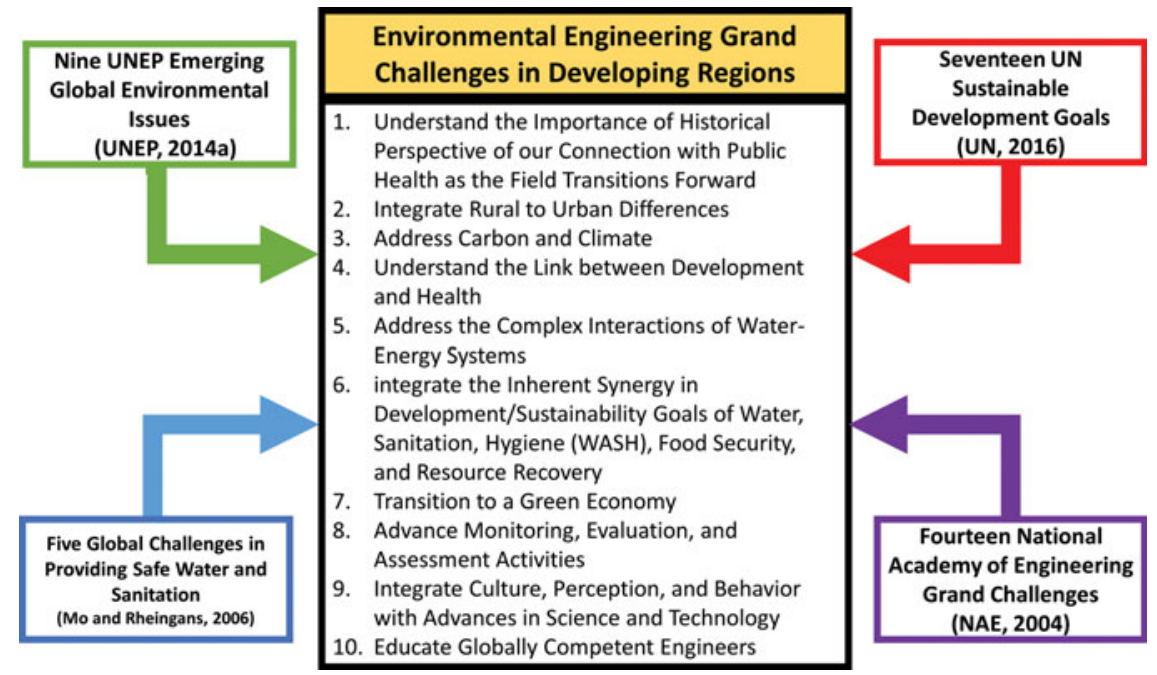

development/sustainability goals of WASH, food security, and resource recovery; (7) transition to a green economy; (8) advance monitoring, evaluation, and assessment activities that include life cycle assessment (LCA), (9) integrate culture, perception, and behavior with advances in science and technology, and (10) develop the global competency of early career engineers. Supplementary Table S1 breaks these 10 Grand Challenges into individual objectives discussed in more detail in this article.

The 10 Grand Challenges identified here help to integrate the aforementioned SDGs as well as other issues and challenges specific to environmental engineers in the developing world context (Fig. 1). For example, the United Nations Environment Programme (UNEP) recently identified nine emerging global environmental issues: (1) excess nitrogen in the environment, (2) emergence of infectious disease, fish, and shellfish farming in marine ecosystems, (3) illegal trade in wildlife, (4) methane from hydrates, (5) realizing the potential of citizen science, (6) air pollution, (7) plastic debris in the ocean, (8) securing soil carbon benefits, and (9) rapid change in the Arctic (UNEP, 2014a). Furthermore, Mo and Rheingans (2006) reviewed five global challenges in the area of providing sanitation and safe water and several of the National Academy of Engineering (NAE) Grand Challenges are immediately important to developing regions; for example, make solar energy economical, manage the nitrogen cycle, provide access to clean water, restore and improve urban infrastructure, advance health informatics, and engineer better medicines. This points to the need for environmental engineering to innovate beyond what is discussed in this article as the discipline charts a path forward to achieve the goal of sustainability, which should be our true north (Anastas, 2010) and our true south.

\section{Grand Challenge 1: Understand the Importance of Historical Perspective as We Transition Forward}

Environmental engineering had its origins in the latter half of the 1800 s, beginning first in the United Kingdom and soon after in the United States. The Great Sanitary Awakening occurred during this period, where sanitary sewers were constructed in cities to eliminate nuisances and protect the public from overloaded cesspools and privy vaults (Fair et al.,
1966). The term sanitary engineer was introduced to describe the branch of civil engineering that focused on wastewater collection to protect public health; it later expanded into the art and science of applying the forces of nature in the planning and construction of works pertaining to public health (Gerhard, 1909).

However, while the introduction of sanitary sewers improved well-being in cities, it exacerbated the problem of downstream surface water pollution. Furthermore, mortality rates of water-transmitted diseases were high in U.S. cities for the first 25 years of the 20th century, being finally lowered with the introduction of filtration and chlorination to water treatment (Fair et al., 1966; Tarr et al., 1980; Cutler and Miller, 2005). The term public health engineer appeared around this time and the American Public Health Association established a public health engineering section in 1921.

Up to the 1970s, the profession of sanitary/public health engineering thus had a long interdisciplinary tradition that was integrated with health professionals; in fact, many of its well-known practitioners and professors held positions in public health departments and even medical schools. Furthermore, from the 1950 s to 1970 s, it was common for sanitary and public health engineering professors to work internationally with organizations such as the World Health Organization (WHO) (publishing several well-known works at the time that include Gotass, 1956; Gloyna, 1971; Okun and Ponghis, 1975) and the U.S. Agency for International Development (USAID) to train professionals at institutions of higher education (USAID, 1966-68). ${ }^{\mathrm{b}}$

Today, environmental engineering is defined as that branch of engineering concerned with the application of scientific and engineering principles for (1) protection of human populations from the effects of adverse environmental factors; (2) protection of environments, both local and global, from the potentially deleterious effects of natural and human activities; and (3) improvement of environmental quality (AAEE, 2009). Many environmental scientists support similar outcomes. Specific areas of focus include air quality and

\footnotetext{
bThe term "sanitary engineer" is still used in many parts of the world (including much of Latin America) and in some locations conveys higher status than environmental engineer.
} 
pollution control, water quality and pollution control, occupational health, stormwater management, and solid and hazardous waste management (AAEE, 2009).

Over time, the discipline evolved to cover additional concerns (e.g., fate and transport of pollutants), but importantly, grew to encompass regional and global concerns (e.g., ozone, climate change). Environmental engineering also evolved from primarily embracing treatment as the preferred method of waste management to integrating more preferred concepts of pollution prevention, industrial ecology, and green engineering that seek to address prevention of pollution and its impact at a waste's earlier life stage (Mihelcic et al., 2003).

While the historical tradition of close alliance between sanitary engineering and health professions gradually disappeared in the United States with the creation of environmental engineering and its focus on large-scale environmental issues, the public health problems that engineers addressed in the early 1900s have not. This historical tradition is still predominant in many parts of the world; for example, in the United Kingdom with works such as Feachem et al. (1983), Cairncross and Feachem (1993), and Mara (1996, 2004) paralleling historical works of Phelps (1948), Salvato (1958), and Gloyna (1971), with the important exception that the newer texts focus on international public health and sanitation.

It is also worth noting that the sanitary revolution that resulted in treated drinking water and adequate excreta disposal has been recognized as the most important medical milestone since 1840 (Ferriman, 2007), and two detailed studies written by health economists, epidemiologists, and public health professionals concluded that the combination of improved sanitation, personal hygiene, and provision of potable water was the principal intervention responsible for U.S. health advances from 1900 to 1930 (Cutler and Miller, 2005; Aiello et al., 2008). This experience offers a valuable model for improving the well-being of developing regions if an adequate public health infrastructure could be developed with the assistance of environmental engineering. We emphasize that this critically important connection between engineering and public health, lost over the past several decades by many educators, researchers, and practitioners in the United States, needs to be reestablished.

\section{Grand Challenge 2: Integrate Rural to Urban Differences}

Knowledge of environmental engineering is not only needed in the wide range of geographical and cultural contexts found between developed and developing regions but also in innovating appropriate solutions over the range of rural to urban locations. The types and magnitudes of environmental health burdens change with increasing affluence, which may differ in these settings. For example, while local urban environmental health burdens can be lessened by provision of improved WASH, new local health burdens may arise from increases in production and affluence (e.g., diabetes, cancer). Furthermore, as an urban population becomes more affluent, the environmental risk may shift from local concerns (e.g., indoor air pollution) to regional concerns (e.g., ambient air pollution) and global environmental burdens (e.g., impact from GHG emissions) (McGranahan et al., 2001).

\section{Urban means more than just megacities}

There appears to be an overemphasis in applying discipline knowledge to problems of large megacities without appropriate consideration of how the context of the problem differs as one moves along the spectrum of rural to largely urban environments. Currently, megacities (population >5-10 million) are viewed by many as the new frontier (especially in regard to more sustainable energy management). In fact, more than half of urban populations in developing regions live in cities with $<500,000$ people (UN, 2011), and cities with $<200,000$ inhabitants make up $12-48 \%$ of some countries' total populations (Oakley and Jimenez, 2012). Even though megacities will continue to experience increased population growth, most future urban population growth is expected to occur in cities of $<500,000$ people (Cohen, 2006). There are many important areas to study in these contexts. For example, within an urban environment, social, gender, and spatial inequalities serve as barriers for residents to access the numerous social, environmental, and economic benefits provided by green space (Wright Wendel et al., 2011, 2012) and much of this green space is also associated with engineering infrastructure. Therefore, engineers have opportunities to collaborate with other disciplines to address these inequalities and ensure equitable opportunities that result in sharing of benefits.

Moreover, small cities are also underserved in areas of government support for environmental services and suffer from financial, institutional, and technology constraints (UNHabitat, 2006). In terms of nutrient flows, populations in small cities in developing regions are clearly linked by geography, watersheds, and many social-economic factors to surrounding agricultural zones that provide opportunities for reclaiming water and embedded nutrients found in domestic wastewater (Verbyla et al., 2013b). Additionally, the environmental needs in informal urban settlements (i.e., urban slums ${ }^{c}$ ), often located within larger cities, are equally challenging and may differ from the needs of small cities. Access to environmental services is remarkably lower in these informal settlements, which currently house 860-880 million of the world's urban population (UN, 2015; UN-Habitat, 2015). These informal urban settings also often have serious problems with violence, safety, and personal security, making them extremely challenging work environments.

\section{Rural area considerations}

Rural areas are important: almost half of the world's population still resides in rural communities and the provision of services in these areas is often neglected. For example, access to improved water and sanitation has consistently lagged in rural areas and 9 of 10 open defecators reside there (WHO and UNICEF, 2014). Furthermore, rural residents are known to depend more on the environment for their economic livelihood than their urban colleagues (WRI, 2005). Rural areas also present a different set of challenges when compared with urban or periurban areas. For example, while management of environmental services in urban locations may be overseen by parastatal corporations or private enterprises, the rural community is often

\footnotetext{
${ }^{\mathrm{c}}$ Urban slums are contiguous and neglected settlements that have characteristics such as (1) inadequate access to safe water, (2) inadequate access to sanitation and infrastructure, (3) poor structural quality of housing, (4) overcrowding, and (5) insecure residential status (UN-Habitat, 2003).
} 
Table 1. Issues to Consider When EnVironmental Engineering and Science Disciplines Work In DifFERENT RuRal and URban ENVIRONMENTS

\begin{tabular}{lcc}
\hline & Challenges & Opportunities \\
\hline Rural areas & $\begin{array}{c}\text { High vulnerability to water scarcity and other } \\
\text { climate change impacts because of strong } \\
\text { reliance on ecosystem services for their }\end{array}$ & $\begin{array}{c}\text { Increasing availability of telecommunication } \\
\text { technologies to facilitate the provision of } \\
\text { livelihood }\end{array}$ \\
$\begin{array}{ccc}\text { Challenges of a globalizing economy, services (e.g., mobile health). } \\
\text { biopatenting of endogenous and }\end{array}$ & $\begin{array}{c}\text { Increasing access to microfinance (i.e., } \\
\text { financial services such as savings, loans, } \\
\text { indigenous knowledge }\end{array}$ & $\begin{array}{c}\text { insurance, money transfer services) to } \\
\text { small businesses and entrepreneurs, as well }\end{array}$ \\
& Lack of economies of scale and access to & as impoverished clients
\end{tabular}

Small cities $(<500,000)$

basic services (e.g., improved water and sanitation facilities)

Low availability of spare parts and low capacity of the private sector to participate in the provision of basic services

Much of the infrastructure is managed and serviced by local committees that are not provided support from outside entities

Demographic shift, including out-migration and aging of rural population, resulting in loss of community leaders to larger cities and increased costs for supporting elderly residents

Lack of financial and institutional capacity and the availability and affordability of technology.

Need for geographically, culturally, and economically appropriate on-site treatment and disposal options

Rapid population growth

Unplanned development and urbanization

Loss of key community leaders and innovators to larger cities

Rise of new environmental health burdens (e.g., diabetes, cancer) with increased affluence (i.e., epidemiological shift)

Urban slums
Violence, insecurity, crime

Economic stagnation in a globalizing world

Growth and liberalization of international trade that includes privatization of goods and services

Land tenure and land rights issues

Reduction of public welfare expenditure and reform of regulation

Many environmental externalities related to transportation, industrial pollution, earth movement, flooding, and solid waste

Urban and development planning that does not consider population growth, both natural and growth from migration from rural areas

Political and social marginalization of the populations

Inability of market to provide adequate and secure housing at affordable prices
Increased global attention to urban resilience, development, socioeconomic and gender equity, and governance structures as key determinants of adaptive capacity

Integrated and sustainable management of natural resources and ecosystems that take mitigation and adaptation action in keeping with the principle of common, but differentiated responsibilities

Opportunities for different development trajectories (i.e., leapfrog old technologies and strategies)

Close proximity to agriculture zones can lead to reclaiming water and embedded nutrients found in domestic wastewater

More open land area that can be incorporated into infrastructure and community wellbeing

Infrastructure improvement should address the livelihood of slum dwellers

Large pool of early adopter and entrepreneurs with high willingness to take risks for opportunities

Increased focus on disaster risk reduction and resilience

Increasing availability of telecommunication technologies to facilitate the provision of essential services

Increasing access to microfinance (i.e., financial services such as savings, loans, insurance, money transfer services) to small businesses and entrepreneurs, as well as impoverished clients 
TABle 1. (CONTINUED)

\begin{tabular}{|c|c|c|}
\hline & Challenges & Opportunities \\
\hline Megacities ( $>5-10$ million) & $\begin{array}{l}\text { Density-related costs result in lost economic } \\
\text { wages } \\
\text { Complexity increases as cities grow } \\
\text { Changing demographic profiles and } \\
\text { economic and social dynamics } \\
\text { Advancements in technology and trends } \\
\text { toward environmental deterioration } \\
\text { Rise of new environmental health burdens } \\
\text { (e.g., diabetes, cancer) with increased } \\
\text { affluence } \\
\text { Congestion costs result in decreased air } \\
\text { quality and lost economic opportunities } \\
\text { Maintaining ecosystem services when large } \\
\text { areas of land are under private ownership } \\
\text { Shift to more regional concerns and global } \\
\text { environmental burdens }\end{array}$ & $\begin{array}{l}\text { Attention to urban resilience, development, } \\
\text { socioeconomic and gender equity, and } \\
\text { governance structures as key determinants } \\
\text { of adaptive capacity } \\
\text { Alternative energy production } \\
\text { Water reuse and nutrient recovery } \\
\text { Advancements in technology and resulting } \\
\text { efficiency gains } \\
\text { Building level gains that lower } \\
\text { environmental burdens }\end{array}$ \\
\hline
\end{tabular}

Sources include UN-Habitat, 2003; Ahrens and Mihelcic, 2006.

left to manage its own systems in developing regions (Schweitzer and Mihelcic, 2012). Table 1 summarizes these and other important issues to consider when working in vastly different contexts that span the rural to urban environment. The information in this table demonstrates that despite the numerous challenges that each of these areas present, there are numerous opportunities to innovate.

\section{Grand Challenge 3: Address Carbon and Climate}

\section{GHGs and climate change}

There is an important and expanding role for the skills of environmental engineers that can be applied to developing region issues related to carbon and climate. However, this first requires an understanding of the differences in regional contributions and ambient concentrations of pollutants and their impact. For example, the GHG emission intensity (i.e., level of GHG emissions per unit of economic output) is higher in developing countries than it is in more industrialized countries. The emission profiles for major GHGs are also documented to differ with a country's development status (Table 2). However, historical contributions to global GHG emissions from 36 countries with developed or emerging economies (e.g., United States, China, European Union, Russia, India, Japan, Brazil, Canada, and S. Korea) account for $\sim 70 \%$ of GHG emissions, while there are 173 other countries that account for only $20 \%$ of the total global emissions (Baumert et al., 2005). Looking to the future, extrapolating trends from individual country pledges to reduce GHG emissions out to 2030 will still lead to an emissions gap between developed and developing regions of 14-17 $\mathrm{Gt} \mathrm{CO}_{2} \mathrm{e}$ (UNEP, 2014b).

These differences point to regional- and country-specific opportunities to develop solutions to mitigate GHG emissions and adapt to the changing climate in developing regions. Least developed countries and small island developing states have negligible GHG emissions and reduction of these is probably not critical for global mitigation efforts; however, the impact of climate change on their health and social and economic well-being is potentially large and catastrophic. Global climate change currently represents a relatively lower risk to human health compared with other environmental burdens; however, the mortality impacts of climate changesensitive health outcomes point to increases in mortality caused by heat, coastal flooding, diarrheal disease, malaria, dengue, and undernutrition (WHO, 2014). Furthermore, impacts of climate change are projected to be greatest for those living in small island developing states and other coastal regions, megacities, and mountainous and polar regions. The impact is also expected to be significant on child health by the 2030s (WHO, 2014).

Climate change is also expected to disproportionately impact communities that rely on snowmelt for their water supply. It also may increase water quality problems associated with algal blooms or surface water runoff from temperature increases and extreme weather events, and the resiliency of water, energy, and food infrastructure will be challenged from more intense cyclone activities (IPCC, 2014). In addition, the access to WASH services, food, and energy infrastructure and the resulting impact on human health and the environment will differ for populations living

Table 2. Emission Profiles (Percent of Total) by Greenhouse Gas and Source

\begin{tabular}{lccc}
\hline & $\begin{array}{c}\text { Developed } \\
\text { countries }\end{array}$ & $\begin{array}{c}\text { Least } \\
\text { Developing } \\
\text { countries }\end{array}$ & $\begin{array}{c}\text { developed } \\
\text { countries* }\end{array}$ \\
\hline $\mathrm{CO}_{2}$ from Fossil Fuels & 81 & 41 & 5 \\
$\mathrm{CO}_{2}$ from land use & $* *$ & 33 & 62 \\
$\quad$ change and forestry & 11 & 16 & 21 \\
$\mathrm{CH}_{4}$ & 6 & 10 & 12 \\
$\mathrm{~N}_{2} \mathrm{O}$ & 2 & 0 & 0 \\
$\begin{array}{l}\text { Fluorinated Gases (i.e., } \\
\left.\quad \mathrm{SF}_{6}, \mathrm{HFCs}, \mathrm{PFCs}\right)\end{array}$ & & & \\
\hline
\end{tabular}

Data from Baumert et al., 2005.

*Least developed countries are defined as a subset of developing countries.

**Land use change and forestry are believed to be net absorbers of $\mathrm{CO}_{2}$ in developed countries. 
in small island developing states (UNEP, 2014c) compared with those residing in dry high-altitude Andean regions of South America (Vergara et al., 2011). There is also currently less effort placed in investigating anthropogenic changes to the hydrologic cycle in most developing regions. As one example, the estimated impacts from climate change were found to be greater than agricultural expansion and associated land use in a wetter and lower altitude region of the Andes, which were found to potentially result in insufficient recharge for springs that provide WASH services to rural developing communities (Fry et al., 2012). There is thus a large role for environmental engineering in understanding how adaptation applies to a country's or development region's unique geographical and socioeconomic setting.

Environmental engineers are well positioned to work in the top five global sectors that contribute to GHG emissions: (1) electricity and heat, (2) transportation, (3) industry, (4) land use changes, and (5) agriculture (WRI, 2005). A discussion on particular levels of GHG emission reduction potential in these five sectors, including co-benefits, barriers, and coverage by national actions and international cooperative initiatives, is provided elsewhere (UNEP, 2014b). Importantly, less carbon-intensive infrastructure and the adaption of existing infrastructure to a lower GHG emission trajectory are possible for all five of these sectors. Research is needed to assess and innovate ways to establish low-cost and functional transportation systems that balance the benefits and environmental and social costs of travel (Bruun and Givoni, 2015). In addition, developing regions are urbanizing rapidly and the rate of new building construction is higher than in developed regions. Cities also account for $70 \%$ of energy use and up to half of GHG emissions (Seto et al., 2014).

There will be a need to develop and implement renewable energy technologies and energy efficiency strategies; however, these must be appropriate, that is, they should use materials and technology that are culturally, economically, and socially suitable to the area in which they are implemented (Mihelcic et al., 2009). For example, one challenge to advancing renewable energy in small island developing states is determining the most appropriate implementation scale of waste-to-energy conversion technologies (UNEP, 2014c). It will also be important to understand how rapid increases in population and affluence in developing regions will impact the contribution and composition of global GHG emissions.

Moreover, a lot of urban energy use is associated with space heating and cooling and hot water provision, which can account for half of building energy consumption (UNEP, 2015). Researching ways to overcome technological and socioeconomic barriers in the implementation of urban district energy systems will be important for expanding and newly created cities to follow a development trajectory with lower carbon intensity. For example, district energy systems are appropriate because they are more climate resilient, more resource efficient, and have lower carbon intensity. They combine energy efficiency improvements with renewable energy integration; integrate the production and supply of heat and cooling with the provision of hot water and electricity; and emphasize the use of local resources and optimize energy efficiency (UNEP, 2015). Furthermore, energy efficiency measures are known to contribute to economic growth, social development, and improved public health. However, improved understanding is needed to determine the magnitude of these positive outcomes, their cultural acceptability, and how they are interrelated while also demonstrating how action on climate change will assist efforts to achieve goals of economic growth and sustainable development (UNEP, 2011; AfDB, 2012; World Bank, 2012).

\section{Other carbon-containing air pollutants}

In addition to carbon dioxide, combustion of fossil fuels results in the emission of other carbon-containing air pollutants, including particulate matter, carbon monoxide, and hazardous air pollutants. Concentrations of particulate matter are higher in countries with lower levels of development, and health burdens associated with ambient and indoor exposure to air pollutants are well documented (Smith, 1993; Bruce et al., 2000). In fact, the world's average $\mathrm{PM}_{10}$ concentrations range from 26 to $208 \mu \mathrm{g} / \mathrm{m}^{3}$ by development region, with the higher values of this range reported in the Americas, sub-Saharan Africa, and Asia (WHO, 2015).

There is still, however, a lack of data on reported $\mathrm{PM}_{10}$ (or $\mathrm{PM}_{2.5}$ ) concentrations in many remote locations, especially sub-Saharan Africa (as well as other conventional air pollutants). Traditional fuel use and cultural preferences related to cooking, heating, and gender allocation of work are known to disproportionately expose women to indoor air with high levels of particulate matter, carbon monoxide, and hazardous air pollutants (Bruce et al., 2000). Furthermore, air emissions and the efficiency of traditional and new generations of household cookstove technology have been assessed (Jetter and Kariher, 2009); however, there is a need to better understand stove performance during the use phase and their overall contribution to climate change (Anenberg et al., 2013).

The energy ladder theory (Smith, 1993) predicts that household fuel type will improve as a household's social and economic statuses increase, resulting in less exposure to particulate matter. However, some families will use their newly acquired economic resources for other household needs instead of purchasing better fuel. Furthermore, as was discussed previously in the Integrate Rural to Urban Differences section, transitioning to different fuels may just redistribute the environmental risk from local populations to regional and global populations.

\section{Grand Challenge 4: Understand the Link Between Development and Health}

\section{Measuring disease burden: risk assessment and disability-adjusted life years}

Environmental health risks are the product of hazard and culturally influenced exposure. Historically, development and infrastructure improvements have altered ecosystems and created new industrial processes, resulting in the emergence of chemical and microbial hazards. Environmental professionals responded to this in the 1970s and 1980s by developing a risk assessment framework (NRC, 1983) and used it to establish regulations for reducing exposure to pollutants in the environment. For example, risk assessment was used in the United States to determine maximum contaminant levels (MCLs) for pollutants in drinking water. 


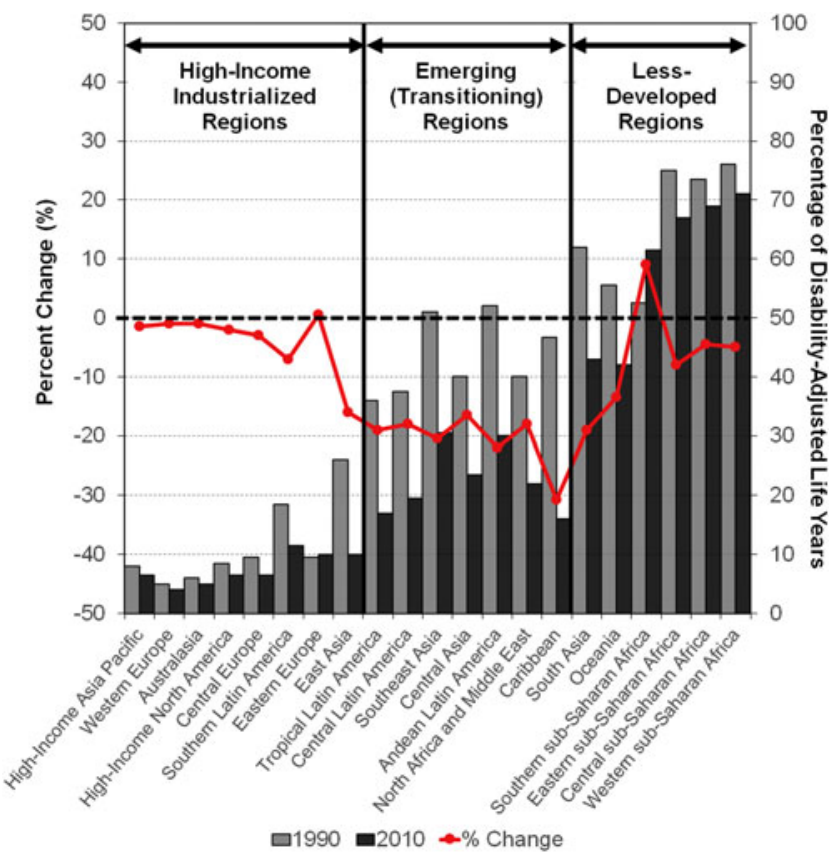

FIG. 2. Contribution of communicable and infectious diseases to the overall disease burden in different global regions in 1990 and 2010 (includes neglected tropical diseases, diarrhea, lower respiratory infections, malaria, tuberculosis, HIV/AIDS, nutritional deficiencies, as well as neonatal and maternal disorders; does not include any other noncommunicable diseases; data from Murray et al., 2012). Note that the increases observed in Eastern Europe and Southern sub-Saharan Africa are primarily due to tuberculosis and/or HIV/AIDs.

Many of these MCLs were determined based on a tolerable maximum probability of $1: 10,000$ to $1: 1,000,000$ that chronically exposed individuals would develop cancer in their lifetime; probabilities that were orders of magnitude lower than the background incidence of cancer in the United States at the time (Munro and Travis, 1986; Mara et al., 2010). However, many MCLs were developed in a postindustrialized setting with relatively low rates of communicable diseases and also during a time when society was developing concern about cancers caused by exposure to chemical pollutants.

Many developing countries have adopted an environmental risk management approach that is based on approaches that were developed for the United States or Europe (e.g., the use of MCLs for managing risk in drinking water). However, the overall health situation varies drastically for different geographical and cultural settings. In the 1990s, the WHO proposed a new measure for disease burden: the disability-adjusted life year (DALY), which incorporates the number of years of life lost due to early death and illness (Murray and Lopez, 1996). This measure helps visualize the extent to which a disease contributes to a region's overall health burden.

Figure 2 shows that in less developed regions, the composition of the disease burden is much different than it is in developed regions. Neglected tropical diseases, diarrheal diseases, malaria, tuberculosis, respiratory infections, and other communicable diseases cause a greater disease burden in developing regions than noncommunicable diseases (e.g., cancer, cardiovascular diseases, diabetes, endocrine diseases); the opposite is true for higher-income countries (Murray et al., 2012). In fact, lower respiratory infections and diarrheal diseases continue to cause the highest and second highest burdens of all diseases in the world, with $>80 \%$ of this disease burden concentrated in low-income countries (WHO, 2008).

The composition of the disease burden in developing and transitioning regions is also changing rapidly. As shown in Fig. 2, between 1990 and 2010, transitioning regions in Asia, North Africa, the Middle East, and Latin America have seen dramatic shifts in the composition of the overall disease burden. For example, in 1990, nearly half of the disease burden in these regions resulted from communicable diseases. By 2010, musculoskeletal disorders, injuries, mental and behavioral disorders, cancer, and cardiovascular diseases comprised a greater percentage of the overall health burden (Murray et al., 2012). This shift was not observed in less developed regions such as South Asia, Oceania, and sub-Saharan Africa, where the majority of the disease burden continues to originate from communicable diseases, neonatal disorders, and nutritional deficiencies (Murray et al., 2012).

\section{Connecting development interventions with health outcomes}

Environmental engineering is uniquely positioned to bridge the gap between sustainable development and health. However, while much previous effort has focused on controlling the adverse effects of environmental factors, protecting the environment from human activities, removing contaminants from air and water, managing waste, and preventing pollution (Mihelcic et al., 2003; AAEE, 2009), the outcomes of this work have not always been directly correlated with culturally appropriate and specific health outcomes. As the discipline transitions forward, environmental engineering will need to bridge this gap and evaluate health outcomes as was discussed for Grand Challenge 1. This has already been done on a broad scale; for example, WASH improvements have been associated with global health impacts (Prüss-Ustün et al., 2014). However, links between technology or culturally appropriate behavior-driven development interventions and health are not as well studied.

In one example, researchers estimated that implementing rainwater harvesting could reduce DALYs by $9 \%$ for urban dwellers in 37 West African cities, and if combined with point-of-use water treatment, the reduction could increase to $16 \%$ (Fry et al., 2010). In another example, despite the demonstrated effectiveness of solar water disinfection in the laboratory, researchers were unable to find strong evidence that the use of solar water disinfection in rural Bolivia significantly reduced rates of gastrointestinal illness (Mäusezahl et al., 2009). A third example from Malawi demonstrated that the increased prevalence of schistosomiasis resulted from changes in fishing techniques to increase yield, which drove snail-feeding fish into deeper waters, causing increased abundance of disease vector snails (Stauffer et al., 2006).

Finally, environmental enteropathy, an inflammation in the intestines that prevents the absorption of nutrients, can lead to child mortality, chronic malnutrition, and reduced 
cognitive development. It can occur in an infant or young child because of inadequate sanitation or hygiene that leads to pathogen exposure from the domestic environment, caretaker's body, drinking water, eating utensils, or even toys (Humphrey, 2009). Environmental enteropathy can be prevented by appropriate interventions in WASH, but further research on the causes and treatments of environmental enteropathy is still required (Humphrey, 2009). This type of research, which links technological and behavioral interventions with specific health outcomes, requires the integration of expertise across multiple

\section{Table 3. Mechanisms of Microbial Disease Emergence in Human Modified Ecosystems}

\begin{tabular}{lccc}
\hline $\begin{array}{l}\text { Mechanisms of } \\
\text { disease emergence }\end{array}$ & $\begin{array}{c}\text { Industrialized food and } \\
\text { energy production systems }\end{array}$ & $\begin{array}{c}\text { Natural ecosystems (dryland, } \\
\text { tropical, coastal) }\end{array}$ & Urban systems
\end{tabular}

\begin{tabular}{|c|c|c|c|}
\hline \multirow[t]{2}{*}{ Habitat alteration } & $\begin{array}{l}\text { Causes: } \\
\text { Construction of dams or } \\
\text { irrigation systems that create new } \\
\text { expanded habitats for disease } \\
\text { vectors (e.g., snails, mosquitoes) }\end{array}$ & $\begin{array}{l}\text { Causes: } \\
\text { Changes in land use and water } \\
\text { management (e.g., deforestation, } \\
\text { algal blooms caused by land } \\
\text { development in coastal regions) }\end{array}$ & $\begin{array}{l}\text { Causes: } \\
\text { Lack of waste management in } \\
\text { cities, creating standing water } \\
\text { and breeding sites for mosquitoes }\end{array}$ \\
\hline & $\begin{array}{l}\text { Examples of diseases: } \\
\text { Schistosomiasis, Japanese } \\
\text { encephalitis, Malaria }\end{array}$ & $\begin{array}{l}\text { Examples of diseases: } \\
\text { Hantavirus, Rift Valley fever, } \\
\text { Meningitis, Malaria, } \\
\text { Arboviruses, Onchocerciasis, } \\
\text { Cholera }\end{array}$ & $\begin{array}{l}\text { Examples of diseases: } \\
\text { Lymphatic filariasis, Dengue } \\
\text { fever, Malaria }\end{array}$ \\
\hline \multirow[t]{2}{*}{$\begin{array}{l}\text { Niche invasion, } \\
\text { host transfer }\end{array}$} & $\begin{array}{l}\text { Causes: } \\
\text { Intensive food production } \\
\text { practices, especially those that } \\
\text { encroach upon forests } \\
\text { (e.g., concentrated animal } \\
\text { operations, adding ground-up } \\
\text { animal remains to feed, wet } \\
\text { markets) }\end{array}$ & $\begin{array}{l}\text { Causes: } \\
\text { Close contact between humans } \\
\text { and other wild animals, } \\
\text { especially primates (e.g., } \\
\text { ecotourism, consumption of } \\
\text { bushmeat) }\end{array}$ & $\begin{array}{l}\text { Causes: } \\
\text { Changes in temperature, rainfall, } \\
\text { and humidity caused by } \\
\text { urbanization or the creation of } \\
\text { human settlements on the } \\
\text { outskirts of urban areas that are } \\
\text { located near sandflies' habitat }\end{array}$ \\
\hline & $\begin{array}{l}\text { Examples of diseases: } \\
\text { Nipah virus, Mad cow disease, } \\
\text { SARS, Influenza }\end{array}$ & $\begin{array}{l}\text { Examples of diseases: } \\
\text { HIV, Ebola, Monkeypox, } \\
\text { Cryptosporidiosis, Giardiasis }\end{array}$ & $\begin{array}{l}\text { Examples of diseases: } \\
\text { Leishmaniasis }\end{array}$ \\
\hline \multirow[t]{2}{*}{$\begin{array}{l}\text { Environmental } \\
\text { contamination }\end{array}$} & $\begin{array}{l}\text { Causes: } \\
\text { Concentrated animal feeding } \\
\text { operations and improper } \\
\text { management } \\
\text { of animal waste }\end{array}$ & $\begin{array}{l}\text { Causes: } \\
\text { Discharge of human waste into } \\
\text { coastal zones and other } \\
\text { recreational waters }\end{array}$ & $\begin{array}{l}\text { Causes: } \\
\text { Lack of wastewater collection } \\
\text { and lack of solid waste } \\
\text { management in urban areas, } \\
\text { spreading human pathogens and } \\
\text { attracting domestic rats and other } \\
\text { pests/disease vectors }\end{array}$ \\
\hline & $\begin{array}{l}\text { Examples of diseases: } \\
\text { Cryptosporidiosis, Leptospirosis }\end{array}$ & $\begin{array}{l}\text { Examples of diseases: } \\
\text { Diarrheal diseases }\end{array}$ & $\begin{array}{l}\text { Examples of diseases: } \\
\text { Leptospirosis, diarrheal diseases }\end{array}$ \\
\hline \multirow[t]{2}{*}{$\begin{array}{l}\text { Human-driven } \\
\text { genetic } \\
\text { changes }\end{array}$} & $\begin{array}{l}\text { Causes: } \\
\text { Overuse and improper use of } \\
\text { antibiotics for human use and for } \\
\text { agricultural uses }\end{array}$ & $\begin{array}{l}\text { Causes: } \\
\text { Overuse of insecticides to } \\
\text { control insect species that serves } \\
\text { as hosts for human disease } \\
\text { agents }\end{array}$ & $\begin{array}{l}\text { Causes: } \\
\text { Overuse of insecticides to control } \\
\text { insect species that serves as hosts } \\
\text { for human disease agents }\end{array}$ \\
\hline & $\begin{array}{l}\text { Examples of diseases: } \\
\text { Multiple drug-resistant }\end{array}$ & $\begin{array}{l}\text { Examples of diseases: } \\
\text { Chagas disease }\end{array}$ & $\begin{array}{l}\text { Examples of diseases: } \\
\text { Chagas disease }\end{array}$ \\
\hline
\end{tabular}
tuberculosis, Methicillinresistant Staphylococcus aureus (MRSA)

Biodiversity
change

Causes:

Fragmentation of animal habitats, elimination of predators to host animals, encroachment by humans into natural animal habitats, causing the extinction of species and the loss of biodiversity, deforestation

\section{Examples of diseases:}

Lyme disease, Leishmaniasis, Onchocerciasis, Rabies

\section{Causes:}

Fragmentation of animal

habitats, elimination of

predators to host animals, encroachment by humans into natural animal habitats, causing the extinction of species and the loss of biodiversity, deforestation

Examples of diseases:
Lyme disease, Leishmaniasis,
Onchocerciasis, Rabies

Causes:

Fragmentation of animal habitats, elimination of predators to host animals, encroachment by humans into natural animal habitats, causing the extinction of species and the loss of biodiversity, deforestation Examples of diseases: Lyme disease, Leishmaniasis, Onchocerciasis, Rabies

Based on Patz and Confalonieri (2005). Copyright (C) 2005 Millennium Ecosystem Assessment. Reproduced by permission of Island Press, Washington, DC. 
disciplines, in this case, public health and social and environmental sciences.

\section{Preventing the emergence of microbial hazards through ecosystem/infrastructure management}

The strategies for controlling microbial hazards in developing regions can be quite complex. Many infectious diseases have emerged or spread as a result of structural anthropogenic changes made to ecosystems that have been facilitated or assessed by engineers (Table 3). For example, habitats have been altered to develop hydroelectricity and irrigated agriculture; however, this practice resulted in increased habitats for snail vectors of schistosomiasis in subSaharan Africa (Steinmann et al., 2006). Intensive food production and animal-feeding operations (intended to increase food security) have enabled pathogens to transfer hosts (from animals to humans) and created strains with increased antibiotic resistance (Graham et al., 2008).

In fact, many of the disease emergence mechanisms summarized in Table 3 are, in part, a result of development practices originally intended to increase food security and/or to eliminate poverty. This information points to a challenge of health consequences of environmental contamination, changing land use, infrastructure construction, habitat fragmentation, urbanization, and addressing demand for water, energy, and food, particularly when the cultural practices of those people most effected are not considered. Also important to consider is the role environmental engineering has in managing disease associated with pandemic viruses that may be found in the urban and agricultural water cycles (Wigginton et al., 2015).

\section{Preventing the emergence of chemical hazards}

Many chemical hazards have recently been introduced into developing regions due to globalization of the world economy (Faber, 2008). While the shifting disease burden in these transitional regions is partly explained by WASH improvements, increased affluence, and the fact that people are living longer, the emergence of new chemical contaminants may also be partially responsible for the shift in disease burden from one centered on microbial hazards and communicable diseases to one that is more centered on emerging chemical hazards. This may be partially responsible for the increased incidence of some cancers and endocrine diseases (Soto and Sonnenschein, 2010). The transition to a green economy (Grand Challenge 7) will require application of the principles of green chemistry (Anastas and Warner, 1998) to eliminate or reduce chemical hazards in developing regions.

\section{Improving approaches to manage disease}

Risk management approaches for developing regions should assess disease burdens and cultural constraints, not simply the probability of diseases. Collaborations with social scientists are needed to understand the distribution and stratification of disease burdens (e.g., how diseases affect genders or cultural/ socioeconomic groups in different ways) and the ways in which history and traditions shape disease patterns. Risk management must also address gaps that may exist between risk perception and reality, understanding that community perceptions about disease may be strongly tied to cultural traditions and that there may be social and environmental consequences of the discon- nects between perception and reality (Cairns, 2015; Whiteford and Vindrola, 2015b; Whiteford et al., 2016).

New molecular tools and techniques can help better understand the relationship between exposure and disease. For example, multiplex, lab-on-chip molecular assays allow for simultaneous detection of multiple pathogens (Tan et al., 2014) and multiplex immunoassays can detect antibodies in saliva (Griffin et al., 2011). These tools will enable researchers to understand which hazards people may have been recently exposed to, providing unique insights into the etiologic agents and vectors associated with disease transmission. Developments in this field could have important impacts, especially in developing regions and with respect to global outbreaks of infectious diseases (e.g., cholera, Ebola virus, Chagas, malaria). These new tools and techniques may allow for future validation of existing risk assessment models (a task that has been difficult in the past due to limitations of traditional epidemiology).

\section{Grand Challenge 5: Address the Complex Interactions of Water-Energy Systems}

Water and energy are two of the most important resources for advancing social and economic well-being. Recognizing their importance, the theme of the UN-coordinated 2014 World Water Day was water and energy. However, nearly half of the world's population will still experience high water stress by 2030 (WWAP, 2012) and energy consumption in some parts of the world, such as China and India, will double in the next 40 years (World Energy Council, 2010).

One challenge in addressing the water-energy nexus is that the components are recognized to be complex, nonlinear, and interconnected (U.S. DOE, 2014). We addressed some issues of energy and climate in a previous grand challenge (3); water issues of governance and natural disasters are also important topics to address in any global water management program (UN Water, 2015a). In fact, flooding and drought are currently considered higher priority threats to water resource management than climate change. However, although the impact of climate change in managing water is viewed as increasingly important for most countries, it is still a lower threat identified by countries with a low human development index (HDI) compared with other issues (UNEP, 2012).

To provide water and wastewater services in the developed world, a large amount of energy is used to move raw water from its source, treat it to a regulatory standard, pump it to end users, and treat it after its use. On the other hand, most energy production is heavily dependent on water (U.S. DOE, 2014), requiring about $8 \%$ of all freshwater withdrawals worldwide (World Economic Forum, 2011). In developing regions, water supply and treatment must not only remain affordable (and thus appropriate for local circumstances) but there are also currently modest financial returns associated with food production. Thus, it will probably not pay to transport water over long distances for agriculture. Furthermore, only $20 \%$ of the wastewater in the world receives proper treatment (reported in WWAP, 2012) and of this, only $8 \%$ is treated in lower-income countries (Sato et al., 2013). Therefore, the existing structure of water management employed in the developed regions may not be applicable to developing regions.

Interactions between water and energy systems have been identified using system archetypes (Zhuang and Zhang, 2015) 


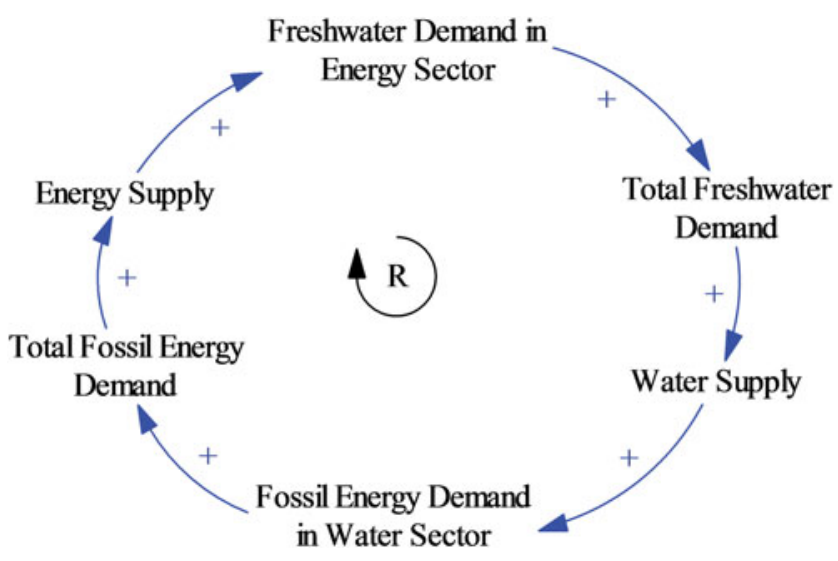

FIG. 3. Reinforcing growth of water and energy demands. The positive sign represents a reinforcing causal relationship. R represents a reinforcing loop (adapted from Zhuang, 2014, with permission).

and development of these for developing contexts is needed. A system archetype is a well-defined structure, which describes the common behavior of a system over time. One fundamental archetype of water and energy systems is reinforcing growth, depicted in Fig. 3. The conventional system is one where the water supply increases with total water demand and leads to the increase in energy demand in water and wastewater treatment and delivery. The increase of energy demand in the water sector leads to increase of total energy demand, which requires more energy supply. This results in the increase in water demand in energy production, especially cooling water for power generation, leading to increase of total water demand [e.g., by $2030, \sim 31 \%$ of industrial water use in China will be for power plant-cooling water (2030 Water Resources Group, 2009)]. This archetype will reinforce the continuous unsustainable increase in water and energy demand over time, exhibiting an exponential growth.

\section{Quantification of water-energy nexus}

Many studies have quantified the energy profile for large water and wastewater utilities in developed world settings (EPRI, 2002; U.S. DOE, 2006; Carlson and Walburger, 2007) or water demand for energy production (U.S. DOE, 2006; Pate et al., 2007; Tidwell et al., 2009). Fewer studies have explored these relationships in developing regions. As one example, the material and human energy required to produce, install, and operate four household-level and four community water source-level interventions was determined in Mali (Held et al., 2013). The systematic analysis of water-energy nexus is also lacking, especially in developing regions that will face more challenges in securing energy for water or water for energy. For example, the expansion of coal power plants in China and India has been determined unfeasible because greater than $50 \%$ are located in areas facing water scarcity (Rodriguez et al., 2013).

In the United States, $\sim 4 \%$ of electricity consumption is used for providing water and wastewater services (U.S. DOE, 2006; Stillwell et al., 2011) and about $41 \%$ of the total freshwater withdrawals are used for thermoelectric generation (Kenny et al., 2009). In Latin America, 30-40\% of operational costs associated with water supply are from energy use (Rosas, 2011). This is thought to be from inefficient system design and operation, poor condition of the assets, low level of metering, reliance on groundwater, and complex topography that may serve low population density areas of service (WWAP, 2014). However, about one half of all countries in the world regard managing water resources for energy production as a low to medium priority.

In contrast, only about one third of low HDI countries value the use of water for energy production as a low to medium priority. The use of water resources for domestic water supply and agriculture is still ranked as the highest priority by majority of countries in the world and managing water resources for ecosystems and the environment is rated as a priority primarily by countries with very high HDI (UNEP, 2012).

Quantifying the water-energy nexus, however, is highly dependent on technologies, scale of implementation, and geographical context. For example, energy consumption for water treatment in developed regions ranges from 0.2 to 1.5 $\mathrm{kWh} / \mathrm{m}^{3}$ water depending on technologies, and wastewater reuse is known to require less energy than more advanced technologies (Cornejo et al., 2014). Furthermore, it is challenging to define energy use by water sector; for example, the energy used for water distribution is estimated to account for $17 \%$ and $29 \%$ of the total electricity in small-scale and largescale systems, respectively (Kumar and Karney, 2007) (similar difficulties exist to define water use by the energy sector).

Natural waste stabilization pond systems used for wastewater treatment throughout the world require negligible energy inputs (Cornejo et al., 2013) compared with $0.3-1.4 \mathrm{kWh} /$ $\mathrm{m}^{3}$ water required for a typical activated sludge with nitrification process now employed in some developed regions (Lazarova et al., 2012). In contrast, household and small-scale water systems using principles of self-supply (Sutton, 2004; MacCarthy et al., 2013) and natural wastewater management technologies that take advantage of photosynthesis, gravity, solar disinfection, and natural assimilation/filtration capacities of land minimize energy use associated with mechanical energy and material inputs (Muga and Mihelcic, 2008).

Regarding the transportation fuels sector, much of the developed world has moved to more water-intensive fuels associated with hydraulic fracturing, biofuels, and hydroelectricity (WWAP, 2014), but it is unknown how this will progress in developing regions.

\section{Integrated water and energy management}

Water and energy management still operates primarily within individual sectors in most countries. The effectiveness of water management options to improve resource use efficiency and reduce environmental impacts is typically only examined on the water side. For example, water and wastewater utilities in developed regions typically consider energy management within the water sector (Table 4). However, energy professionals are not actively involved in water resource management in most global locations (Bowles and Henderson, 2012; Weinzierl and Schilling, 2013; Olmstead, 2014). As such, water and energy tend to be regulated separately in most contexts (Hussey and Pittock, 2012).

Due to the segmental management of water and energy, several issues have surfaced. Strategies in energy planning have resulted in some unintended consequences in water and food systems that need not be repeated as developing regions expand energy production. For example, biofuels can relieve 
Table 4. Energy Management Approaches in Water and Wastewater Sector (LAZAROVA ET $A L .$, 2012; Mo AND ZHANG, 2013)

\begin{tabular}{ll}
\hline Approach & Contribution to energy efficiency \\
\hline $\begin{array}{l}\text { Energy conservation } \\
\text { Heat recovery }\end{array}$ & $\begin{array}{c}\text { Directly reduced energy requirements by reducing energy needed for specific tasks } \\
\text { Heat recovered directly from water stream reduces residential and commercial } \\
\text { energy use } \\
\text { Anaerobic treatment }\end{array}$ \\
$\begin{array}{l}\text { Stabilizes biodegradable organic matter by conversion to biogas, produces energy } \\
\text { source } \\
\text { Combustion of organic matter produces heat to be used directly or for energy } \\
\text { production } \\
\text { Generates electricity from effluent water by using turbines or other devices installed in } \\
\text { conduits }\end{array}$ \\
On-site wind and solar power & $\begin{array}{c}\text { Produces electricity from wind and/or solar energy by taking advantage of the large } \\
\text { land area of the wastewater treatment plants } \\
\text { Direct conversion of organic matter in wastewater to electricity }\end{array}$
\end{tabular}

the stress of fossil fuel demand, but they require a large amount of water in feedstock cultivation (e.g., 9,000100,000 L/GJ for corn) and conversion process (e.g., 47-50 L/GJ for ethanol) while competing with domestic water use (World Economic Forum, 2011).

Even more importantly, biofuel production places pressure on food security because of its demand for food commodity feed stocks (i.e., corn, sugarcane, soy, canola, sunflower, palm oil). Land and water have also been competing priorities for measuring crop production efficiency; land has been the primary focus in agricultural sectors, although future priorities amid water scarcity may require a shift to water-based measures of efficiency (Davies et al., 2011). Furthermore, there is an alignment of food and energy prices because of their overdependence on fossil fuels (UNEP, 2011). Other linkages with food security occur because even though agriculture accounts for $70 \%$ of global water withdrawals, food production and its associated supply chain account for only $30 \%$ of global energy consumption (WWAP, 2014).

On the other hand, the options to address water shortages such as water transfer and seawater desalination require a considerable amount of energy that places stressors on the energy system and may not be applicable to all developing settings. Due to uncoordinated management, the solutions to one resource system may cause unintended consequences to another system. For example, some locations in Hunan province in China received electricity only every third day in March 2011 because of a rationing strategy in response to power shortages (Olsson, 2012). This caused the interruption of water services because treatment plants and pumping stations were also denied energy.

One analysis of integrated water management identified that data sharing across sectors is called for, but generally will not work without policy support to resolve administrative obstacles such as who will maintain the database, who will pay for it, and who will have access to the shared data (McDonnel, 2008). For example, water management models are typically applied to specific watersheds, requiring a high level of hydrological detail; however, the energy planning models typically deal with political boundaries and are concerned with siting and cost requirements. Reconciling the differences between water management and energy planning models will allow integrated water-energy policy analysis and address the shared needs of different stakeholders in both resource systems. Such a modeling framework should be flexible to allow tailored analyses with different levels of data requirements, different geographical and climatic conditions, and different political contexts so that it can be applied to developing regions.

Research is also needed on how reductions in water demand can be achieved by improvements in energy efficiency (and vice versa), especially in the geographical context of different regions and rural versus urban scales (Grand Challenge 2). There is also a need to develop nontechnological solutions that are applicable to the unique socioeconomic circumstances of developing communities and cities. Furthermore, it is critical to recognize the importance of the two distinctly different political economies of water and energy, especially because energy makes up a significantly larger global economic sector compared to water, which is more localized and smaller in terms of its economic impact. In addition, the rate at which new markets, technologies, and mechanisms of governance develop will differ between the two sectors. There is also a great need to develop pricing models that are not solely based on the market but also consider social, cultural, and distributional impacts (WWAP, 2014).

Immense opportunities also exist to study conflict and resolution as they relate to the water-energy nexus because in many developing regions, energy is currently viewed as a commodity, while water is viewed as a human right. With regard to gender inequities, in most parts of the world, women and girls are responsible for most of the daily work effort associated with managing water and energy (from obtaining water to collecting firewood for cooking). In fact, Held et al. (2013) found that women performed over $99 \%$ of the labor associated with seven of eight water supply and household treatment interventions. This discussion also points to opportunities to understand how gender is integrated into a wide variety of development initiatives (e.g., how women use and value the space around a water source, Van Houweling, 2015).

\section{Grand Challenge 6: Integrate the Inherent Synergy Between Development Goals of WASH, Food Security, and Resource Recovery}

The potential to incorporate new technology and strategies in an integrative approach to provide WASH, food security, and recover valuable resources provides an opportunity to utilize knowledge embedded in environmental engineering. Degraded water quality is obviously a major problem in many developing regions. For example, loadings of biochemical oxygen demand and nitrogen from household and 
Table 5. Global Access to Sewer Connection and Treatment by Country Income Group

\begin{tabular}{|c|c|c|}
\hline $\begin{array}{l}\text { Country income } \\
\text { level }\end{array}$ & $\begin{array}{c}\text { Percent of } \\
\text { population } \\
\text { with access to } \\
\text { sewer connection }\end{array}$ & $\begin{array}{c}\text { Percent of } \\
\text { population } \\
\text { with access to sewer } \\
\text { connection and } \\
\text { treatment }\end{array}$ \\
\hline Low income & 3.6 & 0.02 \\
\hline $\begin{array}{l}\text { Lower middle } \\
\text { income }\end{array}$ & 12.7 & 2.0 \\
\hline $\begin{array}{l}\text { Upper middle } \\
\text { income }\end{array}$ & 53.6 & 13.8 \\
\hline High income & 86.8 & 78.9 \\
\hline
\end{tabular}

Based on 2010 data from Baum et al., 2013.

agricultural sources are much higher in developing regions (WWAP, 2003) that lack sanitation and also suffer from food and energy insecurity. Thus, there are opportunities to ensure access to improved water and sanitation while integrating traditional waste management goals to protect human health and the environment and resource recovery goals (Guest et al., 2009). For example, a large source of the total phosphorus available in excreted human waste $(\sim 3.4$ million metric tons) is produced in developing regions such as Africa and Asia that have large populations currently unserved by improved sanitation (Mihelcic et al., 2011). Furthermore, it is estimated that recovering this valuable nutrient could meet $22 \%$ of global phosphorus demand (Mihelcic et al., 2011).

Table 5 shows that a significant percent of the world's population not only does not have access to a sewer connection but also does not see any significant level of centralized treatment or resource recovery of the generated waste. Thus, the integration of on-site sanitation provision with sustainability goals of resource recovery must recognize that an onsite sanitation service chain is prevalent in many parts of the world (or even some combination of on-site and centralized management combined with open defecation). Additionally, this on-site service chain includes not only containment but additional steps of complexity that cover the overall function of the system, that is, waste emptying/removal, transport, treatment, and reuse/disposal (UN Water, 2015b). Each of these steps in the service chain not only provides different opportunities for introducing technology or a behavioral change that leads to recovery of water, energy/heat, and/or nutrients but may also result in different health risks.

However, an added shift in the new way to perceive waste is needed to develop a better understanding about the interconnectedness of problems and solutions to the additional challenges of improving health outcomes with the synergy between WASH, food security, and renewable energy. This synergy is depicted in Fig. 4. Included in this figure is environmental enteropathy (as discussed in Grand Challenge 4), which can be prevented by appropriate interventions in WASH, interventions that can also provide a mechanism to recover critical resources to improve food security and associated positive health outcomes.

\section{Anaerobic digester technology}

Domestic and agricultural waste can also be an important source of energy. For example, $\sim 35$ million household-scale digesters are estimated to be in service throughout the world (UNEP, 2010; Bruun et al., 2014), and China plans to install up to 80 million digesters by 2020 (NDC, 2007). Biogas is an alternative energy source to burning biomass, which is still used for $90 \%$ of household energy consumption in developing regions, causing environmental damage through deforestation and health risks from indoor air pollution (IEA, 2006; Surendra et al., 2014). A variety of common wastes can be used to produce biogas through anaerobic digestion: animal wastes, wastewater biosolids, latrine pit contents, and industrial wastes (Venkateswara Rao et al., 2010; Galvin, 2013; Kinyua et al., 2016). Nutrient and organic material associated with the digestate can be recovered and used as a fertilizer or soil amendment. In addition, anaerobic digestion can reduce the amount of GHG emissions that would otherwise be released from the disposal and burning of biomass for fuels and from chemical fertilizer production (Surendra et al., 2014).

However, many of these digesters are small (ranging from 2 to $10 \mathrm{~m}^{3}$ ) and single stage, being operated under semicontinuous loadings at mesophilic temperatures (between $20^{\circ} \mathrm{C}$ and $35^{\circ} \mathrm{C}$ ) and under different feeding frequencies (Manser et al., 2015a), conditions that are not necessarily
FIG. 4. Synergy between positive and negative health outcomes and goals of water, sanitation, and hygiene (WASH), food security, and waste management.
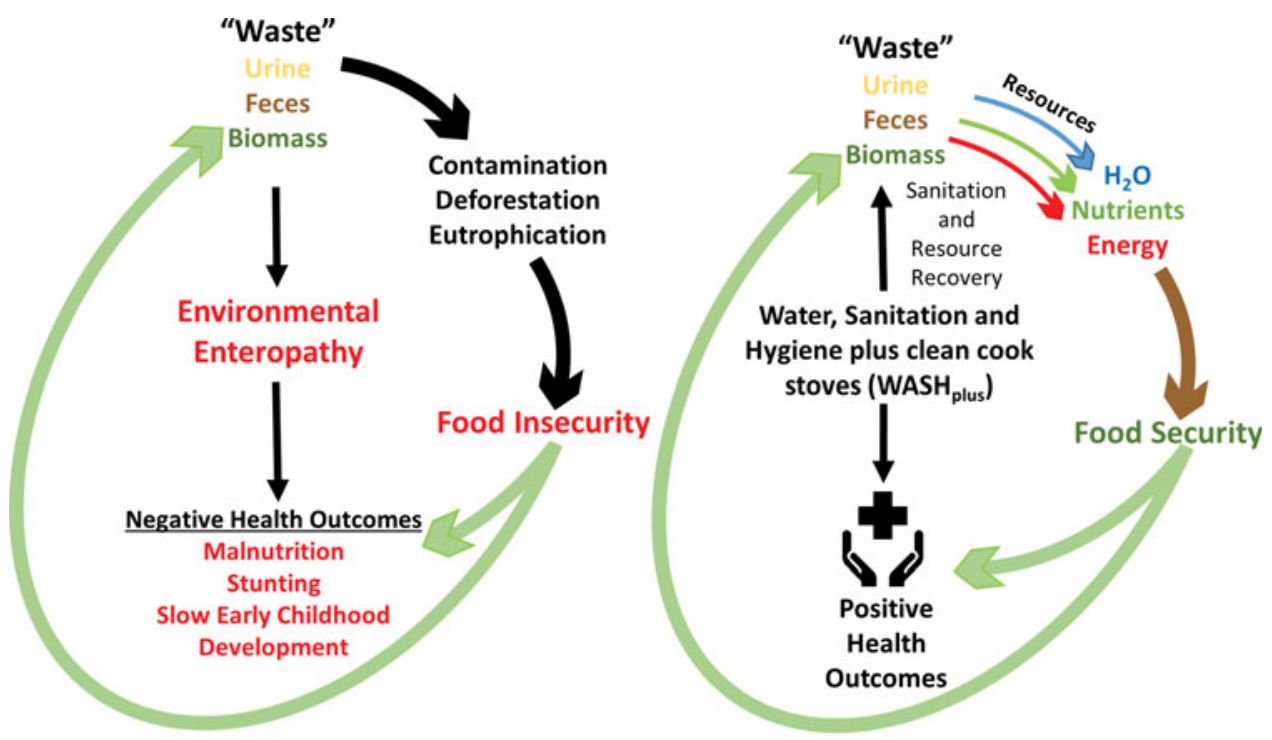
Table 6. Example Biogas Research Needs in Developing Regions of the World

Increase efficiency of biogas digesters in colder climates

Design more affordable and durable biogas digestion systems

Assess efficient digestion of alternative substrates such as straw, kitchen waste, and other biomass

Innovate use of affordable fuel cells in biogas digestion systems to produce electricity

Determine reliability of biogas digester energy supply

Develop better methods of predicting biogas production and consumption

Assess efficient and affordable biogas distribution systems

Evaluate the potential of other available agricultural and food wastes (e.g., straw) that lack chemical properties for efficient fermentation (including codigestion)

Assess health risks associated with reuse of carbon, nitrogen, phosphorus, and other nutrients found in the digestate

Chen et al., 2010; Bond and Templeton, 2011; Bruun et al., 2014; Manser et al., 2015b.

destructive to all human pathogens (Manser et al., 2015b). This has major implications for the safe reuse of potential resources found in the digestate and, importantly, points to the need to better understand the life cycle and fate of geographically relevant pathogens in resource recovery technologies integrated with on-site sanitation (Mehl et al., 2011), anaerobic digestion (Manser et al., 2015b), and wastewater treatment (Verbyla et al., 2013b; Verbyla and Mihelcic, 2015).

There are other nonhealth-related constraints of anaerobic digestion technologies that must be addressed to improve their efficiency, sustainability, and distribution in developing regions (Table 6). For example, it is estimated that only $60 \%$ of digesters in China were operating efficiently (Chen et al., 2010) with even lower values in other countries where biogas digesters are less common, such as sub-Saharan Africa (Bond and Templeton, 2011). Many of these digesters are distributed in a decentralized manner and operated by households and small farms. This provides challenges in understanding local cultures so that energy production can be matched to local demand as well as transfer of a technology that requires sophisticated training.

In addition, although biogas digesters can reduce GHG emissions when properly functioning, it is estimated that up to $40 \%$ of methane $\left(\mathrm{CH}_{4}\right)$ from biogas digesters may be lost due to leaks and direct releases (Bruun et al., 2014). Because methane is a powerful GHG, with a global warming potential 25 times greater than carbon dioxide, improperly operated biogas digesters may be contributing $1 \%$ of global GHG emissions, with a projected increase to $2 \%$ by 2020 (Bruun et al., 2014). Future emphasis on biogas technology should thus include improved maintenance of existing systems rather than construction (Chen et al., 2010), so the technology helps mitigate and not exacerbate GHG emissions (Bruun et al., 2014). A key component of this will be less expensive gas storage and better distribution to more effectively match gas production with demand because the largest contributor to biogas digester GHG emissions is thought to be the intentional release of excess biogas.

The high cost of anaerobic digestion systems is another major limiting factor in adoption. Environmental engineers also need to identify more affordable ways to recover methane from various wastes using low-cost, but durable, anaerobic digestion systems such as polyethylene tubular systems (Venkateswara Rao et al., 2010; Kinyua et al., 2016).

\section{Reclaiming water}

In addition to energy and nutrients, a great resource derived from wastewater is water. Reclaimed water, after site- specific treatment to minimize risk, could be better employed to irrigate and fertilize crops and thus contribute to food security in developing regions. This is important because 20-45 million hectares in the world are now irrigated with reclaimed wastewater (Sato et al., 2013) and approximately threequarters of the world's irrigated area (192 million hectares) is located in developing regions. Complexing this issue is the unavailability of treatment capacity in many of these locations; that is, 1.5 billion people utilize wastewater collection systems that are not served by any treatment (Baum et al., 2013). Integrating wastewater collection and treatment with water and nutrient recovery, even in small communitymanaged systems (serving $<1,000$ residents), can significantly reduce eutrophication potential, embodied energy, and carbon footprint (Cornejo et al., 2013). Further issues to consider are that $87 \%$ of small farms are located in Asia and $8 \%$ in Africa and $90 \%$ of agriculture production in Africa occurs on farms of two hectares or less (UNEP, 2011).

There are also major gains to be made in the overall efficiency of water used for agriculture, which accounts for $70 \%$ of the world's water consumption (FAO, 2002). Particularly, it will be important to improve water efficiency of crop production (FAO, 2002). In fact, the future 30 years of improvements in crop production are expected to be from the blue revolution that will utilize new technologies and strategies (FAO, 2002), which may be more appropriate for a vast number of farms that currently depend on rain-fed agriculture. Environmental engineers may want to focus on improving yields of rain-fed agriculture, which accounts for $60 \%$ of the world's food and 95\% of Africa's cropland (FAO, 2002). Another important component of food security will be the role that urban agriculture plays to improve food security as the shift of populations becomes even further urbanized. Finally, water scarcity will also impact our design and selection of sanitation technology. This is because there may not be sufficient water to operate sanitation technologies that convey waste in sewers and flush toilets, particularly for the 46 million people who live in areas of water scarcity (Fry et al., 2008).

\section{Hygiene and nutrition}

In addition to preventing the spread of infectious diseases, the provision of WASH services can also help ensure nutrient absorption from food, particularly in developing regions, where 791 million of the 805 million people estimated to be chronically undernourished reside (FAO, 2014). Of the four Food and Agriculture Organization (FAO) food security indicators, utilization (of nutrients), which includes access to 
improved water and sanitation, is thought to be the greatest challenge (FAO, 2014). However, existing health impact modeling used to estimate the impact of climate change on undernutrition does not account for nutrient utilization, but instead covers only crop productivity and access (WHO, 2014). Although much progress has been made toward achieving the first MDG of halving those suffering from hunger, incidences of stunting, micronutrient deficiencies, and underweight children remain high throughout developing regions, which may be attributed to diarrheal disease and environmental enteropathy (FAO, 2014; Ngure et al., 2014). It is thus not enough to provide adequate and nutritious food, but importantly sufficient WASH is also required so that food can be properly adsorbed by the human body, particularly in children $\leq 2$ years of age.

For example, the promotion of handwashing (Naughton et al., 2015a) and the use of improved sanitation for those practicing open defecation have been recommended to prevent environmental enteropathy and diarrheal disease, although there is growing concern over children's exposure to fecal contaminants from animals and humans in their play areas (Ngure et al., 2014; Whiteford and Vindrola Padros, 2015a). Thus, environmental engineers, in collaboration with social scientists, will be needed to research the effectiveness of hygiene and sanitation interventions on health burdens caused not only by diarrheal disease but also by stunting and deficiencies in early childhood development. In fact, the concept of baby WASH has been proposed to address the concerns of environmental enteropathy and infectious diseases as an addition to early childhood development programs. This would provide barriers to the key animal and human fecal-oral vectors of hands and hand-to-mouth activity (Ngure et al., 2014).

\section{Grand Challenge 7: Transition to a Green Economy}

There are many opportunities for the discipline of environmental engineering that will emerge as developing regions transition to a green economy. UNEP (2011) envisions the green economy as low in carbon, resource efficient, and socially inclusive. Table 7 provides some characteristics of the green economy. Infrastructures related to providing transportation, shelter, water, and sanitation are seen as key factors for growing the green economy (World Bank, 2012). However, because of inefficiencies in existing infrastructures, there are many opportunities to optimize resource efficiency and productivity gains (AfDB, 2012). Fortunately, repairing, reconditioning, remanufacturing, and recycling are already embedded in the economic structure in developing regions because they require small investments of capital and are relatively labor intensive.

One challenge to achieving a low-carbon economy in developing regions such as Africa will be the presence of proven or probable oil and gas reserves (applicable to 45 of 54 African countries) (AfDB, 2012). Additionally, at this point in time, renewable energy sources, such as hydropower, geothermal, solar, and wind, make up only $1.5 \%$ of the world's primary energy supply (IEA, 2012). Furthermore, in sub-Saharan Africa, the contribution to GDP from mining and quarrying is much larger than economic sectors more familiar to environmental engineering, such as agriculture, manufacturing, transport, construction, electricity, and gas and water (World Bank, 2012).

\section{Solid waste management}

The global waste market is currently worth U.S. \$410 billion/year (includes collection to recycling), excluding the informal sector (UNEP, 2011). The informal sector, if supported to end exploitation, can create economic wellbeing, conserve materials, and reduce pollution (Medina, 2000). Sorting and recycling solid waste also generate 10 times more jobs than landfilling or incineration on a per weight basis (UNEP, 2011). However, generation rates, discard rates, and waste composition differ greatly between rural and urban locations and between developed and developing regions (e.g., there is a greater percent of organics in developing waste streams) (Troschinetz and Mihelcic, 2009).

Also, waste composition is expected to change as a country develops or urbanizes, just as health burdens are expected to change. Furthermore, developing communities may seek options to manage waste at smaller scales. For example, factors designated as incentives to advance waste reduction already exist at the household level in some developing communities, specifically in regard to waste reduction and segregation practices, whereas some barriers exist at the national or regional levels, namely government policies and finances (Post and Mihelcic, 2010; Owens et al., 2011). Furthermore, development and demonstration of appropriate methods to safely dispose of municipal solid waste are desperately needed for small cities and towns (Oakley and Jimenez, 2012).

Table 7. Some Characteristics of the Green Economy (From UNEP, 2011)

Low or zero carbon emitting

Green energy and material inputs replace brown energy and material inputs in manufacturing

Opportunities to reduce waste and inefficiencies,

Develop renewable energy and waste recovery systems

Improve recovery and recycling of scarce resources such as metal ores and water

Closed cycle manufacturing,

Less polluting raw material selection and processing

Integration of by-products into production value chain

Life cycle thinking that leads to extended life of manufacturing products

Self-contained aquaculture systems

Forests are recognized to provide ecosystems, services that include watershed services related to flow regulation, flood protection, and water treatment, and serve as a source of genetic materials, and cultural services.

Inequities in water provision are removed because it is recognized that they result in social costs and economic inefficiencies because of time spent collecting water and/or disposable income devoted to purchase of water 


\section{Grand Challenge 8: Advance Monitoring, Evaluation, and Assessment}

\section{Opportunities and challenges in data collection}

Inherent to advancing sustainable development are tasks related to monitoring, evaluation, and assessment of intervention effectiveness and improvements in health and environmental protection, as well as social and economic well-being. There are large opportunities to use satellite remote sensing and geographical information systems to assess and predict ecosystem responses to environmental change and support development activities in developing regions (Pettorelli et al., 2014; Naughton et al., 2015b).

Recent trends in monitoring, evaluation, and assessment have been toward the use of smart systems that leverage the near ubiquity of telecommunications. Remote sensing and mobile communication technologies are allowing individuals in developing regions to capture and analyze data in real time. In fact, the application of mobile communication technologies to research in developing regions has opened up many research opportunities; for example, determining how payment of water bills with mobile-enabled payment schemes impacts local corruption (Krolikowski, 2014) and how this technology may influence governance of water resources (Mongi et al., 2015). In addition to this machine-to-machine monitoring, there is also increased ability to capture and utilize information from the public through crowd sourcing. These technologies have increased the amount and detail of available data, which in turn lead to better learning and more informed decision-making.

Those working in this area need to partner with governments and other stakeholders to prioritize their objectives with regard to monitoring and evaluation. More importantly, environmental engineers should continue to develop new technologies so that the availability and easy adaption of offthe-shelf systems will allow countries to roll out national monitoring platforms at a lower overall cost. The savings from the development of these systems will allow governments to reallocate funds toward other activities and responsibilities that are often underfunded or do not receive any funding. These include activities related to regulation, governance, and capacity building of local government entities.

Even with advances in data-gathering techniques, one continuing challenge is the lack of sufficient and reliable data. For example, greater than $50 \%$ of countries with a low and medium HDI do not have a management system in place for assessing their water resources (UNEP, 2012). In terms of monitoring systems, countries also report problems with monitoring, often associated with inappropriate technology or the total absence of monitoring networks (UNEP, 2012). Water meters, which have been shown to be an effective economic instrument to change behavior, are still not used in most countries (UNEP, 2012). A survey of 181 countries also revealed that 126 did not have data on wastewater generation, treatment, and use (Sato et al., 2013).

The challenge also remains that monitoring data that are collected and analyzed (along with findings and recommendations) need to be accessible and presented in a format that is easy for all stakeholders to understand. Furthermore, a survey of the indicators currently used at the country level for monitoring and measuring the performance of water resources management suggested that development status does not constrain progress in improving water management. While countries reported having available up to 13 indicators to manage their water resource, they use a smaller number of indicators that would allow for more integrated management (e.g., governance [only 2 indicators], risk assessment [only 3 indicators], human health [only 4 indicators], food, agriculture, and rural livelihoods [only 4 indicators], and ecosystems [only 5 indicators]) (UNEP, 2012). There is also need for indicators that address on-the-ground cultural practices that influence demand and use of water and energy (Whiteford and Vindrola Padros, 2015b). Regarding the study of the water-energy nexus discussed previously (Grand Challenge $5)$, more aggregated data are available on energy than on water provision (WWAP, 2014).

With the passage of the SDGs, organizations and institutions are recognizing the importance of monitoring systems and the value added through coordinated monitoring efforts. In the field of water, wastewater, and ecosystem resources, the WHO and UNICEF created the Joint Monitoring Programme for Water Supply and Sanitation (JMP) and the Global Analysis and Assessment of Sanitation and Drinking Water (GLAAS). UN-Habitat will be developing a complementary tool that will capture data on ambient water quality, expanding on similar data captured under FAO's AQUASTAT. Overall, this GEMI initiative seeks to integrate existing efforts to ensure more harmonized monitoring of the entire water cycle (UN Water, 2016).

\section{Life cycle assessment}

In terms of assessing the environmental sustainability of new technologies or strategies, UNEP and Society of Environmental Toxicology and Chemistry (SETAC) have made the mission of their third phase of the Life Cycle Initiative (2015) to enable the global use of credible life cycle knowledge for more sustainable societies. However, there is still much research and knowledge dissemination required for application of LCA in developing regions.

LCA has been used only to a limited extent in developing regions; for example, in developing a tool to assess the sustainability of WASH projects (McConville and Mihelcic, 2007). It has also been used to determine the embodied material (and sometimes the embodied human energy) of community water supply and household treatment (Held et al., 2013), wastewater treatment integrated with resource recovery (Cornejo et al., 2014), types of household latrines (Galvin, 2013), and traditional and improved methods that support food and economic security (e.g., through the production of shea butter) production (Adams, 2015; Naughton, 2016).Thus, there are many research opportunities and applications to sustainable development particularly in environmental engineering to utilize LCA in developing regions.

Two major reasons LCA is used less in developing settings are because of the lack of both inventory and environmental measurement data as well as lack of institutional knowledge and expertise in LCA (Ahmed, 2012; Bjorn et al., 2013). For example, of 100 LCA networks identified by Bjorn et al. (2013), there were only two in Africa, including the African Life Cycle Assessment Network (ALCANET, 2011). Furthermore, none of the 13 life cycle impact assessments of timber products reviewed by Eshun et al. (2011) were developed for tropical areas such as Africa, but rather for developed regions where 
populations interact differently with their environment. In addition, an environmental impact quantified by LCA such as eutrophication may have a different meaning in a developing region, depending on the access to policy and technology strategies used or nutrient management.

\section{Grand Challenge 9: Integrate Culture, Perception, and Behavior with Advances in Science and Technology}

Benefits of engineering will not be realized through simple technology transfer from developed to developing regions (Lowe et al., 2013). For example, during the Green Revolution of the 1970s, Western development agencies employed teams of social scientists (often after the initial design and intervention) to facilitate the application of agricultural technologies that promised to increase crop yields for reducing poverty and famine. The replacement of traditional farming methods with these new technologies (and their associated costs), however, turned otherwise cooperative farmers into competitors for profit, generating wealth for a few, while exacerbating poverty for many (Michie, 1973; Cohen, 1975). The new technologies were not sustainable in this case because culture and tradition were seen as obstacles to progress and therefore as external to processes of institutional change (Pingali, 2012) instead of being embedded in it (Tucker, 2014).

\section{Complexity of intersecting socioeconomic and environmental factors}

Subsequent research has convincingly demonstrated that factors such as political interests, economic inequalities, social disparities, environmental legacies, and other structural dynamics both enable and constrain community agency (Welker, 2012). These factors combine in complex ways to condition the adoption and sustainability of new technologies (Wells et al., 2016). Moreover, the legitimate involvement of all stakeholders in decision-making processes is known to positively impact the successful implementation of sustainable solutions (Whiteford and Vindrola Padros, 2015a). Unfortunately, most countries, especially those with medium and low HDIs, are making slow progress in engaging stakeholders by providing them access to information, access to decision-making processes, or engaging the public in water resources management (Whiteford et al., 2016).

Africa is particularly notable for falling behind other regions in this regard (UNEP, 2012). Furthermore, Manser et al. (2015b) and Mehl et al. (2011) have demonstrated how engineered technologies now promoted for resource recovery objectives in developed regions in the northern hemisphere may not be sufficient to destroy harmful pathogens common to tropical locations. Users may also adopt such green technology for reasons that are not related to their environmental sustainability (Wilbur, 2014; Trimmer et al., 2016) (e.g., nuisance smells or the issue of flooding in a coastal area may be the drivers in adopting a composting or urine-diverting latrine). There is thus a need to build capacity for community agency to select context-sensitive adaptation strategies and culturally/ geographically appropriate technologies with attention to the structural relationships surrounding communities.

One approach to understanding the complexity of intersecting socioeconomic and environmental factors that inform and are informed by local knowledge is to use complex systems modeling and simulation (Winz et al., 2009; Mirchi et al., 2012; Sharawat et al., 2014). However, some of these approaches have been criticized because they rely on costbenefit (or trade-off) analyses that are based on the principle of maximizing efficiency (Cote and Nightingale, 2012; Andrei and Kennedy, 2013). In developed regions, for example, technology is embedded in the marketplace, which favors efficiency to reduce costs (and wastes) and increase benefits (and profits). Such ideals have influenced Western notions of sustainability, especially in the engineering sector (Bell et al., 2011; Grant et al., 2012; Wan Alwi et al., 2014).

However, in many developing regions, technological systems are often not driven by market forces alone, but instead are embedded in social institutions that operate on different values and principles (Jackson, 2006). For example, in some communities, the operation of water and sanitation systems may be organized through kinship relationships (Fleuret, 1985) or religious institutions (Lansing, 1987), neither of which necessarily makes decisions based on rational notions of efficiency (Orlove and Caton, 2010).

\section{Importance of social science}

Recognizing these differences, environmental engineers need to be aware that social science is making two important contributions to situating novel technologies in different cultural and geographic settings. First, by studying how and why people draw on social or moral values to guide decisionmaking, local perceptions of human-environmental phenomena can be understood. One example of this is the negative reactions at the idea of using resources derived from wastes, such as is often encountered with reclaimed or recycled water.

The social sciences can also help discern how to incorporate local perceptions of purity and pollution into understanding how people engage with waste reclamation technologies and products (Po et al., 2005; Whiteford and Whiteford, 2005; Nancarrow et al., 2008; Rodriguez et al., 2009; Russell and Lux, 2009; Mankad, 2012). Doing so can obviate the inherent problems in using behavioral incentives to encourage changes in practice, which often assume that people are lazy (and therefore require motivation), uninformed (and therefore require education), or self-interested (and therefore require a change in values). In many developing settings, individual choice - and the ability to carry out actions - is often constrained by structural conditions, including social obligation, access to resources, and local politics.

One solution to this challenge is for environmental engineers to incorporate tools such as those employed in social marketing. Social marketing is the application of marketing skills and tools for noncommercial purposes, such as changing perceptions and practices to enhance health status. When applied to the discipline of environmental engineering, this translates into social scientists incorporating ethnographic research methods (e.g., interviews and focus groups) and program evaluation to influence the voluntary behavior of the target population for the benefit of the public (Kotler and Zaltman, 1971; Andreasen, 1995, 2006; Brown, 1997; Lee and Kotler, 2011; Guang and Borges, 2012). This approach has proven especially useful in the context of recovering resources from wastewater (Johnson, 2003; Doria et al., 2009; Dolnicar et al., 2010; Dolnicar and Hurlimann, 2011; Kemp et al., 2012). 
A second way in which the environmental engineering discipline needs to understand how social sciences can contribute to the sustainability of context-sensitive technologies is through basic research that results in enhanced understanding of social and cultural settings for technology deployment. The primary unit of development intervention is often the community, which is defined based on the residential proximity of households to one another (Conning and Kevane, 2002; Mansuri and Rao, 2004). However, social science research has shown that communities are not simple geographical constructs, but have multiple sociospatial and sociopolitical meanings to their residents (Israel et al., 1998). Moreover, these meanings can shift, sometimes significantly, depending on the stakeholder groups involved (Billgreen and Holmén, 2008). Water and sanitation systems and watershed and ecosystem management can thus cross multiple communities and be subject to larger institutional arrangements at multiple scales as well as imbalances in the distribution of resources (Linton, 2014; Linton and Budds, 2014; Whiteford et al., 2015a).

Such challenges of scale (Cash et al., 2006) sometimes lead to misunderstandings and miscommunications that can impede the sustainability of water systems (Marston, 2000; Norman et al., 2012; Haarstad, 2014). Social science research shows that communities should not be idealized as internally homogeneous and externally bounded entities. Instead, communities are historically changing networks of actors and institutions operating according to diverse motivations and desires (Wells et al., 2014). From this perspective, the contexts and conditions, as well as the social and spatial scales, in which people make decisions about resource use, can be revealed (MacKinnon, 2010).

\section{Grand Challenge 10: Educate Globally Competent Engineers}

Developing the global competency of engineers is critical for solving all the grand challenges discussed in this special issue. The NRC (1999) and the NAE (2004) have previously called for engineers to be educated in global competency. Furthermore, the Accreditation Board for Engineering and Technology (ABET) has stated through Criterion 3(h) that all engineering graduates should have a broad education necessary to understand the impact of engineering solutions in a global, economic, environmental, and societal context. Global competency has been defined as the ability for an engineering student to understand and work effectively with engineers and other coworkers from countries other than the student's own country, especially those who may solve and define problems differently than the student (Downey et al., 2006). Four core competencies have been identified as a framework to develop engineering curriculum and training programs: (1) development of language and cultural skills, (2) teamwork and group dynamics, (3) knowledge of international business and engineering cultures, and (4) knowledge of variations in international engineering education and practice (NRC, 1999).

Importantly, Shen et al. (2011) have performed comparative studies that demonstrate the importance of international experiences in the development of global competency. What is troubling is that during the 2012/ 2013 academic year, 144,804 international engineering students studied in the United States while fewer than 12,000 U.S. engineering students did any learning abroad (this number does not include noncredit work, internships, and volunteering abroad). Furthermore, the number of engineering students studying abroad makes up only $4.1 \%$ of the 289,408 U.S. students who studied abroad in 2012/2013. U.S. engineering students also have one of the lowest participation rates by field of study; in fact, more health professional students study abroad and their international engineering student colleagues' participation is only eclipsed by business and marketing majors (IIE, 2014).

While several education programs exist to develop global competency of early career engineers (Mihelcic et al., 2006; Mihelcic et al., 2008; Trotz et al., 2009; Mihelcic, 2010; Jesiek et al., 2014), most engineering educators still assume this is a topic to be addressed in courses taken in social sciences and humanities. Further complicating the development of global competency is that only $3 \%$ of U.S. students study abroad for an academic or calendar year; $60 \%$ of all U.S. students who study abroad only travel internationally for a short term (i.e., summer or $\leq 8$ weeks). Programs such as the Peace Corps Master's International program for civil and environmental engineering graduate students use a nontraditional university partnership and place students overseas for $2+$ years of education, engineering practice, and research (Mihelcic, 2004, 2010; Mihelcic et al., 2006; Manser et al., 2015c).

What is especially needed is to revise curriculums and cocurricular programming to integrate the four core global competencies, promote high-impact educational practices, including service learning and study abroad, employ nontraditional learning methods such as social media (Verbyla et al., 2014), globalize our environmental engineering textbooks (such as was done in Mihelcic and Zimmerman, 2014), develop nontraditional partnerships (Mihelcic, 2010), advance existing methods to evaluate global competency (Widmann and Vanasupa, 2008; Jesiek et al., 2012; Manser et al., 2015c), take better advantage of international students in our classrooms and laboratories, and determine how to provide international opportunities to a larger and more diverse group of students, especially those who have financial need. We have also determined that the international research experience is more transformational if the student engages in meaningful work-related activities outside a laboratory (Vernaza-Hernandez and Feldman, 2016).

As a holistic, comparative, and action-oriented field of applied research, sustainability science can be used in the implementation of these practices to help students understand the ways and extent to which they are interconnected with other people and places across the globe and how their beliefs and behaviors influence and are influenced by these interconnections. Doing so can cultivate students as engaged global citizens skilled in problem solving, attentive to human diversity and cultural complexity, and instilled with a sense of personal and social responsibility to address present and future Grand Challenges particularly those in developing regions.

\section{Summary}

Environmental engineering has a critical role in assuring the well-being of the global population and must continue to adapt to current and future challenges and collaborate with 
existing and new partner disciplines. In this study, we present 10 Grand Challenges that the discipline of environmental engineering can address to improve the social, economic, and environmental well-being of present and future generations in developing regions of the world. Our hope is that this discussion leads to a better world through monumental improvements in the environment and human well-being and drives new innovations and opportunities in education, research, practice, and service. Most importantly, any transfer of technology and strategies must consider local climatic, health, socioeconomic, and cultural conditions so that mutually beneficial outcomes between developed and developing regions can be attained (Mihelcic et al., 2007).

\section{Acknowledgments}

This material is based upon work supported by the National Science Foundation under Grant No. 1243510 and the Graduate Research Fellowship Program awarded to Dr. Verbyla under Grant No. 1144244. During this time period, Dr. Naughton held an American Fellowship from the American Association of University Women (AAUW).

\section{Author Disclosure Statement}

No competing financial interests exist.

\section{References}

Acharya, T. (2007). Science and technology for wealth and health in developing countries. Glob. Public Health 2, 53.

Adams, E. (2015). Carbon Dioxide (CO2) Emissions, Human Energy, and Cultural Perceptions Associated with Traditional and Improved Methods of Shea Butter Processing in Ghana, West Africa. Master of Science in Mechanical Engineering Thesis, University of South Florida, Tampa, FL.

Adams, W.M., Aveling, R., Brockington, D., Dickson, B., Elliot, J., Hutton, J., Roe, D., Vira, B., and Wolmer, W. (2004). Biodiversity conservation and the eradication of poverty. Science 306, 1146.

African Development Bank (AfDB). (2012). Towards Green Growth in Africa. African Development Bank Report. Available at: www.afdb.org/en/documents/document/africandevelopment-report-2012-towards-green-growth-31845/ (accessed June 8, 2016).

African Life Cycle Assessment Network (ALCANET). (2011). ALCANET Charter. Available at: www.estis.net/sites/alcanet/ (accessed June 8, 2016).

Ahmed, K. (2012). Getting to Green: A Sourcebook of Pollution Management Policy Tools for Growth and Competitiveness. Washington, DC: World Bank. Available at: http://documents .worldbank.org/curated/en/2012/01/16565836/getting-greensourcebook-pollution-management-policy-tools-growthcompetitiveness (accessed June 8, 2016).

Ahrens, B.T., and Mihelcic, J.R. (2006). Making wastewater construction projects sustainable in urban, rural, and peri-urban areas. J. Eng. Sustain. Dev. Energy Environ. Health 1, 13.

Aiello, A.E., Larson, E.L., and Sedlak, R. (2008). Hidden heroes of the health revolution: Sanitation and personal hygiene. Am. J. Infect. Control 36, S128.

Akers, D.B., MacCarthy, M.F., Cunningham, J.A., Annis, J., and Mihelcic, J.R. (2015). Lead (Pb) contamination of selfsupply groundwater systems in coastal Madagascar and predictions of blood lead levels in exposed children. Environ. Sci. Technol. 49, 2685.
American Academy of Environmental Engineers (AAEE). (2009). Environmental Engineering Body of Knowledge. AAEE, the Environmental Engineering Body of Knowledge Task Force. Available at: www.aaees.org/publicationseebodyofknowledge.php (accessed June 8, 2016).

Anastas, P. (2010). ORD: The Path Forward. Memorandum to U.S. EPA Office of Research and Development, from Anastas, P.T., Assistant Administrator. Available at http://yosemite.epa .gov/sab/sabproduct.nsf/796BB04146A5F14C852576F9004E5E 69/\$File/Anastas+Path+Forward+3-5-10.pdf (accessed June 8, 2016).

Anastas, P.T. (2012). Fundamental changes to EPA's research enterprise: The path forward. Environ. Sci. Technol. 46, 580.

Anastas, P.T., and Warner, J.C. (1998). Green Chemistry: Theory and Practice. Oxford, England, UK: Oxford University Press.

Andreasen, A.R. (1995). Marketing Social Change: Changing Behavior to Promote Health, Social Development and the Environment. San Francisco, CA: Jossey-Bass.

Andreasen, A.R. (2006). Social Marketing in the 21st Century. Thousand Oaks, CA: Sage Publications, Inc.

Andrei, A.L., and Kennedy, W.G. (2013). Agent-based models and ethnography: Combining qualitative and computational techniques with complexity theory. Pract. Anthropol. 35, 29.

Anenberg, S.C., Balakrishnan, K., Jetter, J., Masera, O., Mehta, S., Moss, J., and Ramanathan, V. (2013). Cleaner cooking solutions to achieve health, climate, and economic cobenefits. Environ. Sci. Technol. 47, 3944.

Baum, R., Luh, J., and Bartram, J. (2013). Sanitation: A global estimate of sewerage connections without treatment and the resulting impact on MDG progress. Environ. Sci. Technol. 47, 1994.

Baumert, K.A., Herzog, T., and Pershing, J. (2005). Navigating the Numbers: Greenhouse Gas Data and International Climate Policy. World Resources Institute. Available at: www .wri.org/publication/navigating-numbers (accessed June 8, 2016).

Bell, S., Chilvers, A., and Hillier, J. (2011). The sociotechnology of engineering sustainability. Proc. ICE-Eng. Sustain. 164, 177.

Billgreen, C., and Holmén, H. (2008). Approaching reality: Comparing stakeholder analysis and cultural theory in the context of natural resource management. Land Use Policy 25, 550.

Bjorn, A., Owsianiak, M., Laurent, A., Molin, C., Westh, T.B., and Hauschild, M.Z. (2013). Mapping and characterization of LCA networks. Int. J. Life Cycle Assess. 18, 812.

Bond, T., and Templeton, M.R. (2011). History and future of domestic biogas plants in the developing world. Energy Sustain. Dev. 15, 347.

Bowles, F.J., and Henderson, P. (2012). Water resource management-The water utilities view. Fish. Manag. Ecol. 19, 484.

Brown, C. (1997). Anthropology and social marketing: A powerful combination. Pract. Anthropol. 19, 27.

Bruce, N., Perez-Padilla, R., and Albalak, R. (2000). Indoor air pollution in developing countries: A major environmental health challenge. Bull. World Health Organ. 78, 1079.

Bruun, S., Soumann Jensen, L., Thi Khanh Vu, V., and Sommer, S. (2014). Small-scale household biogas digesters: An option for global warming mitigation or a potential climate bomb? Renew. Sustain. Energy Rev. 33, 736.

Bruun, E., and Givoni, M. (2015). Sustainable Mobility: Six research routes to steer transport policy. Nature 523, 29.

Cairncross, S., and Feachem, R. (1993). Environmental Health Engineering in the Tropics: An Introductory Text. New York: John Wiley \& Sons.

Cairns, M.R. (2015). Want not, waste not? Analyzing alternative strategies for wastewater management. Presented at the 
75th Annual Meeting of the Society for Applied Anthropology. Pittsburgh, PA, March 24-25.

Carlson, S.W., and Walburger, A. (2007). Energy Index Development for Benchmarking Water and Wastewater Utilities. Denver, CO: AWWA Research Foundation.

Cash, D.W., Adger, W.N., Berkes, F., Garden, P., Lebel, L., Olsson, P., Pritchard, L., and Young, O. (2006). Scale and cross-scale dynamics: Governance and information in a multilevel world. Ecol. Soc. 11, 8.

Chen, Y., Yang, G., Sweeney, S., and Feng, Y. (2010). Household biogas use in rural China: A study of opportunities and constraints. Renew. Sustain. Energy Rev. 14, 545.

Clasen, T.F., Brown, J., Collin, S., Suntura, O., and Cairncross, S. (2004). Reducing diarrhea through the use of householdbased ceramic water filters: A randomized, controlled trial in rural Bolivia. Am. J. Trop. Med. Hyg. 70, 651.

Cohen, B. (2006). Urbanization in developing countries: Current trends, future projections, and key challenges for sustainability. Technol. Soc. 28, 63.

Cohen, J.M. (1975). Effects of green revolution strategies on tenants and small-scale landowners in the Chilalo region of Ethiopia. J. Dev. Areas 9, 335.

Conning, J., and Kevane, M. (2002). Community-based targeting mechanisms for social safety nets: A critical review. World Dev. 30, 375.

Cornejo, P.K., Santana, M.V.E., Hokanson, D.R., Mihelcic, J.R., and Zhang, Q. (2014). Carbon footprint of water reuse and desalination: A review of greenhouse gas emission and estimation tools. J. Water Reuse Desalination 4, 238.

Cornejo, P.K., Zhang, Q., and Mihelcic, J.R. (2013). Quantifying benefits of resource recovery from sanitation provision in a developing world setting. J. Environ. Manag. 131, 7.

Cote, M., and Nightingale, A.J. (2012). Resilience thinking meets social theory: Situating social change in socio-ecological systems (SES) research. Prog. Hum. Geogr. 36, 475.

Cutler, D., and Miller, G. (2005). The role of public health improvements in health advances: The twentieth-century United States. Demography 42, 1.

Davies, W.J., Zhang, J., Yang, J., and Dodd, I.C. (2011). Novel crop science to improve yield and resource use efficiency in water-limited agriculture. J. Agric. Sci 149, 123.

Dolnicar, S., and Hurlimann, A. (2011). Water alternatives: Who and what influences public acceptance? J. Public Affairs 11, 49.

Dolnicar, S., Hurlimann, A., and Nghiem, L.D. (2010). The effect of information on public acceptance-The case of water from alternative sources. J. Environ. Manag. 91, 1288.

Doria, M.F., Pidgeon, N., and Hunter, P.R. (2009). Perceptions of drinking water quality and risk and its effect on behaviour: A cross-national study. Sci. Total Environ. 407, 5455.

Downey, G.L., Lucena, J.C., Moskal, B.M., Parkhurst, R., Bigley, T., Hays, C., Jesiek, B.K., Kelly, L., Miller, J., Ruff, S., Lehr, J.L., and Nichols-Belo, A. (2006). The globally competent engineer: Working effectively with people who define problems differently. J. Eng. Educ. 95, 107.

Electric Power Research Institute (EPRI). (2002). Water \& Sustainability (Volume 4): U.S. Electricity Consumption for Water Supply \& Treatment-The Next Half Century. Palo Alto, CA: EPRI.

Eshun, J.F., Potting, J., and Leemans, R. (2011). LCA of the timber sector in Ghana: Preliminary impact assessment (LCIA). Int. J. Life Cycle Assess. 16, 625.

Exley, J.L.R., Liseka, B., Cumming, O., and Ensink, J.H.J. (2015). The sanitation ladder, what constitutes an improved form of sanitation? Environ. Sci. Technol. 49, 1086.
Faber, D. (2008). Capitalizing on Environmental Justice: The Polluter-Industrial Complex in the Age of Globalization. Washington, DC: Rowman \& Littlefield Publishers.

Fair, G.M., Geyer, J.G., and Okun, D.A. (1966). Water and Wastewater Engineering, Vol. 1: Water Supply and Wastewater Removal. New York: John Wiley \& Sons.

Food and Agricultural Organization (FAO). (2002). Crops and Drops: Making the Best of Water for Agriculture. Rome: FAO of the United Nations. Available at: www.fao.org/ docrep/005/y3918e/y3918e00.htm (accessed June 8, 2016).

Food and Agricultural Organization (FAO). (2014). The State of Food Insecurity in the World. Rome: FAO of the United Nations. Available at: www.fao.org/publications/sofi/ 2014/en/ (accessed June 8, 2016).

Feachem, R.G., Bradley, D.J., Garelick, H., and Mara, D.D. (1983). Sanitation and Disease: Health Aspects of Excreta and Wastewater Management. World Bank Studies in Water Supply and Sanitation. New York: John Wiley \& Sons. Available at: http://documents.worldbank.org/curated/en/ 1983/01/439534/sanitation-disease-health-aspects-excretawastewater-management (accessed June 8, 2016).

Ferriman, A. (2007). BMJ readers choose the "sanitary revolution" as greatest medical advance since 1840. Br. Med. J. 334, 111.

Fleuret, P. (1985). The social organization of water control in the Taita Hills, Kenya. Am. Ethnol. 12, 103.

Fry, L.M., Cowden, J.R., Watkins, D.W., Clasen, T., and Mihelcic, J.R. (2010). Quantifying health improvements from water quantity enhancement: An engineering perspective applied to rainwater harvesting in West Africa. Environ. Sci. Technol. 44, 9535.

Fry, L.M., Mihelcic, J.R., and Watkins, D.W. (2008). Water and nonwater-related challenges of achieving global sanitation coverage. Environ. Sci. Technol. 42, 4298.

Fry, L.M., Schweitzer, R.W., and Mihelcic, J.R. (2013). Water, human health, and sustainable development. In: S. Ahuja, Ed., Comprehensive Water Quality and Purification, Vol. 4. Waltham, MA: Elsevier, p. 299.

Fry, L.M., Watkins, D.W., Reents, N., Rowe, M.D., and Mihelcic, J.R. (2012). Climate change and development impacts on the sustainability of spring-fed water supply systems in the Alto Beni Region of Bolivia. J. Hydrol. 468$469,120$.

Galvin, C.M. (2013). Embodied Energy and Carbon Footprint of Household Latrines in Rural Peru: The Impact of Integrating Resource Recovery. Master of Science in Environmental Engineering Thesis, University of South Florida. Available at: http://scholarcommons.usf.edu/etd/4489/ (accessed June 8, 2016).

Gerhard, W.P. (1909). Sanitation and Sanitary Engineering, 2nd Ed. Boston: Stanbope Press.

Gloyna, E.F. (1971). Waste Stabilization Ponds. Geneva, Switzerland: World Health Organization.

Gotass, H.B. (1956). Composting: Sanitary Disposal and Reclamation of Organic Waste. Geneva, Switzerland: World Health Organization.

Graham, J.P., Leibler, J.H., Price, L.B., Otte, J.M., Pfeiffer, D.U., Tiensin, T., and Silbergeld, E.K. (2008). The animalhuman interface and infectious disease in industrial food animal production: Rethinking biosecurity and biocontainment. Public Health Rep. 123, 282.

Grant, S.B., Saphores, J.-D., Feldman, D.L., Hamilton, A.J., Fletcher, T.D., Cook, P.L.M., Stewardson, M., Sanders, B.F., Levin, L.A., Ambrose, R.F., Deletic, A., Brown, R., Jiang, 
S.C., Rosso, D., Cooper, W.J., and Marusic, I. (2012). Taking the "waste" out of "wastewater" for human water security and ecosystem sustainability. Science 337, 681.

Griffin, S.M., Chen, I.M., Fout, G.S., Wade, T.J., and Egorov, A.I. (2011). Development of a multiplex microsphere immunoassay for the quantitation of salivary antibody responses to selected waterborne pathogens. J. Immunol. Methods 364, 83.

Guang, T., and Borges, L. (2012). The effectiveness of social marketing mix strategy: Towards an anthropological approach. Int. J. Bus. Anthropol. 3, 102.

Guest, J.S., Skerlos, S.J., Barnard, J.L., Beck, M.B., Daigger, G.T., Hilger, H., Jackson, S.J., Karvazy, K., Kelly, L., Macpherson, L., Mihelcic, J.R., Pramanik, A., Raskin, L., Van Loosdrecht, M.C.M., Yeh, D., and Love, N.G. (2009). A new planning and design paradigm to achieve sustainable resource recovery from wastewater. Environ. Sci. Technol. 43, 6126.

Haarstad, H. (2014). Climate change, environmental governance and the scale problem. Geogr. Compass 8, 87.

Harris, A.R., Davis, J., and Boehm, A.B. (2013). Mechanisms of post-supply contamination of drinking water in Bagamoyo, Tanzania. J. Water Health 11, 543.

Hasan, A., Patel, S., and Satterthwaite, D. (2005). How to meet the millennium development goals (MDGs) in Urban Areas. Environ. Urban. 17, 3.

Held, B.R., Zhang, Q., and Mihelcic, J.R. (2013). Quantification of human and embodied energy of improved water provided by source and household interventions. J. Clean. Prod. $60,83$.

Humphrey, J.H. (2009). Child undernutrition, tropical enteropathy, toilets, and handwashing. Lancet 374, 1032.

Hussey, K., and Pittock, J. (2012). The energy-water nexus: Managing the links between energy and water for a sustainable future. Ecol. Soc. 17, 31.

Hutton, G., and Bartram, J. (2008). Global costs of attaining the Millennium Development Goal for water supply and sanitation. Bull. World Health Organ. 86, 1.

Institute of International Education (IIE). (2014). Open Doors Report on International Educational Exchange. Available at: www.iie.org/opendoors (accessed June 8, 2016).

Intergovernmental Panel on Climate Change (IPCC). (2014). Climate Change 2014: Impacts, Adaptation, and Vulnerability. Part A: Global and Sectoral Aspects. Contribution of Working Group II to the Fifth Assessment Report of the Intergovernmental Panel on Climate Change. C.B. Field, V.R. Barros, D.J. Dokken, K.J. Mach, M.D. Mastrandrea, T.E. Bilir, M. Chatterjee, K.L. Ebi, Y.O. Estrada, R.C. Genova, B. Girma, E.S. Kissel, A.N. Levy, S. MacCracken, P.R. Mastrandrea, and L.L. White, Eds. Cambridge, United Kingdom and New York: Cambridge University Press.

International Energy Agency (IEA). (2006). Chapter 15: Energy for cooking in developing countries. In World Energy Outlook 2006. Paris, France: IEA. Available at: www.iea.org/ publications/freepublications/publication/cooking.pdf (accessed June 8, 2016).

International Energy Agency (IEA). (2012). World Energy Outlook 2012. Paris, France: IEA. Available at: www.worldenergy outlook.org/publications/weo-2012/ (accessed June 8, 2016).

Israel, B.A., Schulz, A.J., Parker, E.A., and Becker, A.B. (1998). Review of community-based research: Assessing partnership approaches to improve public health. Annu. Rev. Public Health 19, 173.

Jackson, S. (2006). Compartmentalising culture: The articulation and consideration of indigenous values in water resource management. Aust. Geogr. 37, 19.
Jesiek, B.K., Haller, Y., and Thompson, J. (2014). Developing globally competent engineering researchers: outcomes-based instructional and assessment strategies from the IREE 2010 China research abroad program. Adv. Eng. Educ. 4, 1.

Jesiek, B.K., Shen, Y., and Haller, Y. (2012). Cross-cultural competence: A comparative assessment of engineering students. Int. J. Eng. Educ. 28, 144.

Jetter, J.J., and Kariher, P. (2009). Solid-fuel household cook stoves: Characterization of performance and emissions. Biomass Bioenergy 33, 294.

Johnson, B.B. (2003). Do reports on drinking water quality affect customers' concerns? Experiments in report content. Risk Anal. 23, 985.

Kemp, B., Randle, M., Hurlimann, A., and Dolnicar, S. (2012). Community acceptance of recycled water: Can we inoculate the public against scare campaigns? J. Public Aff. 12, 337.

Kenny, J.F., Barber, N.L., Hutson, S.S., Linsey, K.S., Lovelace, J.K., and Maupin, M.A. (2009). Estimated Use of Water in the United States in 2005. Reston, VA: U.S. Geological Survey.

Kinyua, M.N., Rowse, L.E., and Ergas, S.J. (2016). Review of small-scale tubular anaerobic digesters treating livestock waste in the developing world. Renew. Sustain. Energy Rev. $58,896$.

Kotler, P., and Zaltman, G. (1971). Social marketing: An approach to planned social change. J. Mark. 35, 3.

Krolikowski, A. (2014). Can mobile-enabled payment methods reduce petty corruption in urban water provision? Water Altern. 7, 235.

Kumar, G., and Karney, B.W. (2007). Electricity usage in water distribution networks Montreal, Canada. Proceeding of 2007 IEEE Canada Electrical Power Conference. p. 97.

Lansing, J.S. (1987). Balinese "water temples" and the management of irrigation. Am. Anthropol. 89, 326.

Lazarova, V., Choo, K.H., and Cornel, P. (2012). Water-Energy Interactions in Water Reuse. London: IWA publishing.

Lee, K., Walt, G., and Haines, A. (2004). The challenge to improve global health. J. Am. Med. Assoc. 291, 2636.

Lee, N.R., and Kotler, P. (2011). Social Marketing: Influencing Behaviors for Good. Los Angeles, CA: Sage Publications, Inc.

Life Cycle Initiative. (2015). 2012-2016: Flagship Activities and Response to New Challenges. UNEP and SETAC. Available at: www.lifecycleinitiative.org/activities/phase-iii/ (accessed June 8, 2016).

Linton, J. (2014). Modern water and its discontents: A history of hydrosocial renewal. WIREs Water 1, 111.

Linton, J., and Budds, J. (2014). The hydrosocial cycle: Defining and mobilizing a relational-dialectical approach to water. Geoforum 57, 170.

Lowe, P., Phillipson, J.J., and Wilkinson, K. (2013). Why social scientists should engage with natural scientists. Contemp. Soc. Sci. 8, 207.

MacCarthy, M.F., Annis, J.E., Mihelcic, J.R. (2013). Unsubsidised self-supply in Eastern Madagascar. Water Altern. 6, 424.

MacKinnon, D. (2010). Reconstructing scale: Towards a new scalar politics. Prog. Hum. Geogr. 35, 21.

Mankad, A. (2012). Decentralised water systems: Emotional influences on resource decision making. Environ. Int. 44, 128.

Manser, N., Naughton, C., Prouty, C., Orner, K., Verbyla, M., and Mihelcic, J.R. (2015c) Improving the global competency of graduate engineers through Peace Corps partnership and long-term international service making value for society. Proceedings of the American Society for Engineering Education (ASEE) National Conference. Seattle, WA, June 2015. 
Manser, N.D., Mihelcic, J.R., and Ergas, S.J. (2015a). Semicontinuous mesophilic anaerobic digester performance under variations in solids retention time and feeding frequency. Bioresour. Technol.190, 359.

Manser, N.D., Wald, I., Ergas, S.J., Izurieta, R., and Mihelcic, J.R. (2015b). Assessing the fate of Ascaris suum ova during mesophilic anaerobic digestion. Environ. Sci. Technol. 49, 3128.

Mansuri, G., and Rao, V. (2004). Community-based and -driven development: A critical review. World Bank Res. Obs. 19, 1.

Mara, D. (1996). Low-Cost Urban Sanitation. Chichester, United Kingdom: John Wiley \& Sons.

Mara, D. (2004). Domestic Wastewater Treatment in Developing Countries. London: Earthscan.

Mara, D., Hamilton, A.J., Sleigh, A., and Karavarsamis, N. (2010). Options for Updating the 2006 WHO Guidelines. Geneva, Switzerland: World Health Organization.

Marks, S.J., Komives, K., and Davis, J. (2014). Community participation and water supply sustainability: Evidence from handpump projects in rural Ghana. J. Plann. Educ. Res. 34, 276.

Marston, S.A. (2000). The social construction of scale. Prog. Hum. Geogr. 24, 219.

Mäusezahl, D., Christen, A., Pacheco, G.D., Tellez, F.A., Iriarte, M., Zapata, M.E., Cevallos, M., Hattendorf, J., Cattaneo, M.D., Arnold, B., Smith, T.A., and Colford, J.M. (2009). Solar drinking water disinfection (SODIS) to reduce childhood diarrhoea in Rural Bolivia: A cluster-randomized, controlled trial. PLoS Med. 6, e1000125.

McConville, J.R., and Mihelcic, J.R. (2007). Adapting life cycle thinking tools to evaluate project sustainability in international water and sanitation development work. Environ. Eng. Sci. 24, 937.

McDonnell, R.A. (2008). Challenges for integrated water resources management: How do we provide the knowledge to support truly integrated thinking? Int. J. Water Resour. Dev. 24, 131.

McGranahan, G., Jacobi, P., Songsore, J., Surjadi, C., and Kjellen, M. (2001). The Citizens at Risk: From Urban Sanitation to Sustainable Cities. London: Earthscan.

Medina, M. (2000). Scavenger cooperatives in Asia and Latin America. Resour. Conserv. Recycl. 31, 51.

Mehl, J., Kaiser, J., Hurtado, D., Gibson, D.A., Izurieta, R., and Mihelcic, J.R. (2011). Pathogen destruction and solids decomposition in composting latrines: Study of fundamental mechanisms and user operation in Rural Panama. J. Water Health 9, 187.

Michie, B.H. (1973). Variations in economic behavior and the Green Revolution: An anthropological perspective. Econ. Polit. Wkly. 8, A67.

Mihelcic, J.R. (2004). Educating the future's water professional. Water Environ. Technol. 16, 86.

Mihelcic, J.R. (2010). The right thing to do: Graduate education and research in a global and human context. In G.L. Downey and K. Beddoes, Eds., What Is Global Engineering Education For? The Making of International and Global Engineering Educators. San Francisco, CA: Morgan \& Claypool Publishers, pp. 235-250.

Mihelcic, J.R., Crittenden, J.C., Small, M.J., Shonnard, D.R., Hokanson, D.R., Zhang, Q., Chen, H., Sorby, S.A., James, V.U., Sutherland, J.W., and Schnoor, J.L. (2003). Sustainability science and engineering: The emergence of a new metadiscipline. Environ. Sci. Technol. 37, 5314.

Mihelcic, J.R., Fry, L.M., and Shaw, R. (2011). Global potential of phosphorus recovery from human urine and feces. Chemosphere 84, 832.
Mihelcic, J.R., Myre, E.A., Fry, L.M., Phillips, L.D., and Barkdoll, B.D. (2009). Field Guide in Environmental Engineering for Development Workers: Water, Sanitation, Indoor Air. Reston, VA: American Society of Civil Engineers (ASCE) Press.

Mihelcic, J.R., Paterson, K.G., Phillips, L.D., Zhang, Q., Watkins, D.W., Barkdoll, B., Fuchs, V.J., Fry, L.M., and Hokanson, D.R. (2008). Educating engineers in the sustainable futures model with a global perspective. Civil Eng. Environ. Syst. 25, 255.

Mihelcic, J.R., Phillips, L.D., and Watkins, D.W. (2006). Integrating a global perspective into engineering education and research: Engineering international sustainable development. Environ. Eng. Sci. 23, 426.

Mihelcic, J.R., and Zimmerman, J.B. (2014). Environmental Engineering: Fundamentals, Sustainability, Design, 2nd Edition. New York: John Wiley \& Sons.

Mihelcic, J.R., Zimmerman, J.B., and Ramaswami, A. (2007). Integrating developed and developing world knowledge into global discussions and strategies for sustainability. 1. Science and technology. Environ. Sci. Technol. 41, 3415.

Millennium Ecosystem Assessment. (2005). Ecosystems and Human Well-being. Washington, DC: Island Press.

Mirchi, A., Madani, K., Watkins, D., Jr., and Ahmad, S. (2012). Synthesis of system dynamics tools for holistic conceptualization of water resources problems. Water Resour. Manag. 26, 2421.

Mo, C.L., and Rheingans, R.D. (2006). Global challenges in water, sanitation, and health. J. Water Health 4, 41.

Mo, W., and Zhang, Q. (2013). Energy-nutrients-water Nexus: Integrated resource recovery in municipal wastewater treatment plants. J. Environ. Manag. 127, 255.

Mongi, H.J., Mvuma, A.N., Kucel, S., Tenge, A.J., and Gabriel, M. (2015). Accessibility and utilization of mobile phones for governance of water resources in the Lake Victoria Basin: Constraints and opportunities in Tanzania. Afr. J. Environ. Sci. Technol. 9, 438.

Muga, H.E., and Mihelcic, J.R. (2008). Sustainability of wastewater treatment technologies. J. Environ. Manag. 88, 437.

Munro, N.B., and Travis, C.C. (1986). Drinking-water standards: Risks for chemicals and radionuclides. Environ. Sci. Technol. 20, 768.

Murray, C.J.L., and Lopez, A.D. (1996). Global Burden of Disease: A Comprehensive Assessment of Mortality and Disability from Diseases, Injuries, and Risk Factors in 1990 and Projected to 2020. Cambridge, MA: Harvard University Press.

Murray, C.J.L., Vos, T., Lozano, R., Naghavi, M., Flaxman, A.D., Michaud, C., Ezzati, M., Shibuya, K., Salomon, J., et al. (2012). Disability-adjusted life years (DALYs) for 291 diseases and injuries in 21 regions, 1990-2010: A systematic analysis for the Global Burden of Disease Study 2010. Lancet 380, 2197.

Nancarrow, B.E., Leviston, Z., Po, M., Porter, N.B., and Tucker, D.I. (2008). What drives Communities' decisions and behaviours in the reuse of wastewater. Water Sci. Technol. 57, 485. National Academy of Engineering (NAE). (2004). The Engineer of 2020: Visions of Engineering in the New Century. Washington, DC: The National Academies Press.

National Development and Reform Commission (NDC). (2007). Medium and Long-Term Development Plan for Renewable Energy in China. Beijing: National Development and Reform Commission.

National Research Council (NRC). (1983). Risk Assessment in the Federal Government: Managing the Process. Washington, DC: National Academy Press. 
National Research Council (NRC). (1999). Engineering Tasks for the New Century: Japanese and U.S. Perspectives, Washington, DC: The National Academies Press.

Naughton, C.C. (2016). Modeling Food Security, Energy, and Climate and Cultural Impacts of a Process: The Case Study of Shea Butter in Sub-Saharan Africa. Doctor of Philosophy in Civil Engineering Dissertation, University of South Florida, Tampa, FL.

Naughton, C.C., Lovett, P.N., and Mihelcic, J.R. (2015b). Land suitability of shea (Vitellaria paradoxa) distribution across Sub-Saharan Africa. Appl. Geogr. 58, 217.

Naughton, C.C., Sissoko, H.T., and Mihelcic, J.R. (2015a). Assessing factors that lead to usage of appropriate technology handwashing stations in Mali, West Africa. J. Water Sanit. Hyg. Dev. 5, 279.

Ngure, F.M., Reid, B.M., Humphrey, J.H., Mbuya, M.N, Pelto, G., and Stoltzfus, R.J. (2014). Water, sanitation and hygiene (WASH), environmental enteropathy, nutrition, and early child development: Making the links. Ann. N. Y. Acad. Sci. 1308, 118.

Norman, E.S., Bakker, K., and Cook, C. (2012). Introduction to the themed section: Water governance and the politics of scale. Water Altern. 5, 52.

Oakley, S.M., and Jimenez, R. (2012). Sustainable sanitary landfills for neglected small cities in developing countries: The semi-mechanized trench method from Villanueva, Honduras. Waste Manag. 32, 2535.

Okun, D.A., and Ponghis, G. (1975). Community Wastewater Collection and Disposal. Geneva, Switzerland: World Health Organization.

Olmstead, S.M. (2014). Climate change adaptation and water resource management: A review of the literature. Energy Econ. 46, 500.

Olsson, G. (2012). Water and Energy: Threats and Opportunities. London: IWA publishing.

Orlove, B., and Caton, S.C. (2010). Water sustainability: Anthropological approaches and prospects. Annu. Rev. Anthropol. 39, 401.

Owens, E.L., Zhang, Q., and Mihelcic, J.R. (2011). Material flow analysis to improve solid waste management in small island developing states. J. Environ. Eng. 137, 937.

Pate, R., Hightower, M., Cameron, C., and Einfeld, W. (2007). Overview of Energy-Water Interdependencies and the Emerging Energy Demands on Water Resources. SAND 2007-1349C. Los Alamos, NM: Sandia National Laboratories.

Patz, J.A., and Confalonieri, U.E.C. (2005). Human health: Ecosystem regulation of infectious diseases. In R. Hassan, R. Scholes, and N. Ash, Eds., Ecosystems and Human WellBeing: Current State and Trends, Volume 1. Washington, DC: Island Press, pp. 391-416.

Pettorelli, N., Safi, K., and Turner, W. (2014). Satellite remote sensing, biodiversity research and conservation of the future. Philos. Trans. R. Soc. Lond. B Biol. Sci. 369, 20130190.

Phelps, E. (1948). Public Health Engineering. New York: John Wiley \& Sons.

Pingali, P.L. (2012). Green revolution: Impacts, limits, and the path ahead. Proc. Natl. Acad. Sci. U. S. A. 109, 12302.

Po, M., Nancarrow, B.E., Leviston, Z., Porter, N.B., Syme, G.J., and Kaercher, J.D. (2005). Predicting Community Behaviour in Relation to Wastewater Reuse: What Drives Decisions to Accept or Reject. Perth, Australia: CSIRO Land and Water.

Population Reference Bureau. (2014). 2014 World Population Data Sheet. Washington, DC. Available at: www.prb.org/
Publications/Datasheets/2014/2014-world-population-datasheet/data-sheet.aspx (accessed June 8, 2016).

Post, J.L. and Mihelcic, J.R. (2010). Waste Reduction Strategies for Improved Management of Household Solid Waste in Jamaica. Int. J. Environ. Waste Manag. 6, 4.

Prüss-Ustün, A., Bartram, J., Clasen, T., Colford, J.M., Cumming, O., Curtis, V., Bonjour, S., Dangour, A.D., De France, J., Fewtrell, L., Freeman, M.C., Gordon, B., Hunter, P.R., Johnston, R.B., Mathers, C., Mäusezahl, D., Medlicott, K., Neira, M., Stocks, M., Wolf, J. and Cairncross, S. (2014). Burden of disease from inadequate water, sanitation and hygiene in lowand middle-income settings: A retrospective analysis of data from 145 countries. Trop. Med. Int. Health 19, 894.

Prüss-Üstün, A., and Corvalán, C. (2006). Preventing Diseases Through Healthy Environments: Towards an Estimate of the Environmental Burden of Disease. Geneva, Switzerland: World Health Organization.

Rehfuess, E., Mehta, S., and Prüss-Üstün, A. (2006). Assessing household solid fuel use: Multiple implications for the millennium development goals. Environ. Health Perspect. 114, 373.

Rodriguez, C., Van Buynder, P., Lugg, R., Blair, P., Devine, B., Cook, A., and Weinstein, P. (2009). Indirect potable reuse: A sustainable water supply alternative. Int. J. Environ. Res. Public Health 6, 1174.

Rodriguez, D.J., Delgado, A., DeLaquil, P., and Sohns, A. (2013). Thirsty Energy. Water papers. Washington, DC; World Bank. Available at: http://documents.worldbank.org/ curated/en/2013/01/17932041/thirsty-energy (accessed June $8,2016)$.

Rosas, R. (2011). La eficiencia energética en empresas de agua y saneamiento en países de América Latina y e Caribe (mejores prácticas y lecciones aprendidas) [The energy efficiency of water and sanitation authorities in Latin American and Caribbean countries (best practices and lessons learned)]. Washington, DC: Inter-American Development Bank (IADB).

Russell, S., and Lux, C. (2009). Getting over yuck: Moving from psychological to cultural and sociotechnical analyses of responses to water recycling. Water Policy 11, 21.

Salamanca-Buentello, F., Persad, D.L., Court, E.B., Martin, D.K., Daar, A.S., and Singer, P.A. (2005). Nanotechnology and the developing world. PLoS Med. 2, e97.

Salvato, J. (1958). Environmental Sanitation. New York: John Wiley \& Sons.

Sato, T., Qadir, M., Yamamoto, S., Endo, T., and Zahoor, A. (2013). Global, regional, a country level need for data on wastewater generation, treatment, and use. Agric. Water Manag. 130, 1.

Schafer, C.A., and Mihelcic, J.R. (2012). Effect of storage tank material and maintenance on household water quality. J. Am. Water Works Assoc. 104, E521.

Schweitzer, R.W., Cunningham, J.A., and Mihelcic, J.R. (2013). Hydraulic modeling of clay ceramic water filters for point-of-use water treatment. Environ. Sci. Technol. 47, 429.

Schweitzer, R.W., and Mihelcic, J.R. (2012). Assessing sustainability of community management of rural water systems in the developing world. J. Water Sanit. Hyg. Dev. 2, 20.

Seto, K.C., et al. (2014). Chapter 12: Human settlements, infrastructure and spatial planning. In O. Edenhofer, et al., Eds., Climate Change 2014: Mitigation of Climate Change. Contribution of Working Group III to the Fifth Assessment Report of the Intergovernmental Panel on Climate Change. Cambridge, United Kingdom and New York: Cambridge University Press, pp. 923-1000. 
Sharawat, I., Dahiya, R.P., Dahiya, R., and Kumari, S. (2014). System dynamics approach: A novel water resource management tool. Int. J. Environ. Res. Dev. 14, 297.

Shen, Y., Jesiek, B.K., Chang, Y. (2011). Cultural Orientation and Global Competency: A Comparative Assessment of Engineering Students." Proceedings of the Annual Conference of the American Society for Engineering Education, Vancouver, Canada, June 26-29.

Smith, K.R. (1993). Fuel combustion, air pollution exposure, and health: The situation in developing countries. Annu. Rev. Energy Environ. 18, 529.

Soto, A.M., and Sonnenschein, C. (2010). Environmental causes of cancer: Endocrine disruptors as carcinogens. Nat. Rev. Endocrinol. 6, 363.

Stauffer, J.R., Madsen, H., McKaye, K., Konings, A., Bloch, P., Ferreri, C.P., Likongwe, J., and Makaula, P. (2006). Schistosomiasis in Lake Malawi: Relationship of fish and intermediate host density to prevalence of human infection. EcoHealth 3, 22.

Steinmann, P., Keiser, J., Bos, R., Tanner, M., and Utzinger, J. (2006). Schistosomiasis and water resources development: Systematic review, meta-analysis, and estimates of people at risk. Lancet Infect. Dis. 6, 411.

Stillwell, A.S., King, C.W., Webber, M.E., and Duncan, I.J. (2011). The energy-water nexus in Texas. Ecol. Soc. 16, 2.

Surendra, K.C., Takara, D., Hashimoto, A.G., and Khanal, S.K. (2014). Biogas as a sustainable energy source for developing countries: Opportunities and challenges. Renew. Sustain. Energy Rev. 31, 846.

Sutton, S. (2004). Self Supply: A Fresh Approach to Water for Rural Populations. Nairobi, Kenya and St Gallen, Switzerland: WSP, RWSN, DFID. Available at: www.rural-watersupply.net/en/resources/details/273 (accessed June 8, 2016).

Tan, J.J.L., Capozzoli, M., Sato, M., Watthanaworawit, W., Ling, C.L., Mauduit, M., Malleret, B., Grüner, A.-C., Tan, R., Nosten, F.H., Snounou, G., Rénia, L., and Ng, L.F.P. (2014). An integrated lab-on-chip for rapid identification and simultaneous differentiation of tropical pathogens. PLoS Negl. Trop. Dis. 8, e3043.

Tarr, J.A., Yosie, T., and McCurley 3rd, J. (1980). Disputes over water quality policy: Professional cultures in conflict, 1900-1917. Am. J. Public Health 70, 427.

Tidwell, V.C., Kobos, P.H., Malczynski, L., Klise, G., Hart, W.E., and Castillo, C. (2009). Decision Support for Integrated Water-Energy Planning. Albuquerque, NM and Livermore, CA: Sandia National Laboratories.

Trimmer, J.T., Nakyanja, N., Ssekubugu, R., Sklar, M., Mihelcic, J.R., and Ergas, S.J. (2016). Assessing the promotion of urinediverting dry toilets through school-based demonstration facilities in Kalisizo, Uganda. J. WASH Dev. [Epub ahead of print] DOI: 10.2166/washdev.2016.045

Troschinetz, A.M., and Mihelcic, J.R. (2009). Sustainable recycling of municipal solid waste in developing countries. Waste Manag. 29, 915.

Trotz, M.A., Muga, H.E., Phillips, L.D., Yeh, D. Stuart, A., and Mihelcic, J.R. (2009). Non-traditional university research partners that facilitate service learning and graduate research for sustainable development. Proceedings 2009 World Environmental \& Water Resources Congress. Kansas City, MO, May 17-21, 2009.

Tucker, B. (2014). Rationality and the green revolution. In M.A. Gibson and D.W. Larson, Eds., Applied Evolutionary Anthropology: Darwinian Approaches to Contemporary World Issues. New York: Springer.

United Nations (UN). (2011). Population Distribution, Urbanization, Internal Migration and Development: An International
Perspective. United Nations Department of Economic and Social Affairs Population Division. Available at: www.un.org/esa/ population/publications/PopDistribUrbanization/Population DistributionUrbanization.pdf (accessed June 8, 2016).

United Nations (UN). (2015). The Millennium Development Goals Report 2015. New York: United Nations.

United Nations (UN). (2016). Sustainable Development Goals: 17 Goals to Transform Our World. Available at: www.un.org/ sustainabledevelopment/sustainable-development-goals/ (accessed June 8, 2016).

United Nations Environment Programme (UNEP). (2010). Waste and Climate Change: Global Trends and Strategy Framework. Nairobi, Kenya: United Nations Environment Programme Division of International Environmental Technology Centre.

United Nations Environment Programme (UNEP). (2011). Towards a Green Economy: Pathways to Sustainable Development and Poverty Eradication. St-Martin-Bellevue, France: UNEP. Available at: https://sustainabledevelopment.un.org/index.php? page $=$ view $\&$ type $=400 \& n r=126 \&$ menu $=35$ (accessed June 8, 2016).

United Nations Environment Programme (UNEP). (2012). Status Report on the Application of Integrated Approaches to Water Resources Management. Available at: www.unwater .org/publications/publications-detail/en/c/204523/ (accessed June 8, 2016).

United Nations Environment Programme (UNEP). (2014a). UNEP Year Book: Emerging Issues in Our Global Environment, 2014. Nairobi, Kenya. Available at: www.unep.org/ yearbook/2014/ (accessed June 8, 2016).

United Nations Environment Programme (UNEP). (2014b). The Emissions Gap Report 2014. Nairobi, Kenya. Available at: www.unep.org/publications/ebooks/emissionsgapreport2014/ (accessed June 8, 2016).

United Nations Environment Programme (UNEP). (2014c). GEO Small Island Developing States Outlook. Nairobi, Kenya.

United Nations Environment Programme (UNEP). (2015). District Energy in Cities: Unlocking the Potential of Energy Efficiency and Renewable Energy. Available at: www.unep .org/energy/districtenergyincities (accessed June 8, 2016).

UN-Habitat. (2003). The Challenges of Slums-Global Report on Human Settlements 2003. UN Human Settlements Programme, Earthscan, London.

UN-Habitat (2006). Meeting Development Goals in Small Urban Centres: Water and Sanitation in the World's Cities. UN Human Settlements Programme, Earthscan, London.

UN-Habitat. (2015). Urbanization for Prosperity. UN Human Settlements Programme, April 2015. Available at: https:// issuu.com/unhabitat/docs/urbanization_for_prosperity_policy_ (accessed June 8, 2016).

UN Water. (2015a). Report on the Achievements during the International Decade for Action Water for Life 2005-2015. R. Ardakanian, J. Liebe, and L.M. Bernhardt, Eds. Bonn, Germany: UN-Water Decade Programme on Capacity Development (UNW-DPC). Available at: www.ais.unwater .org/water-for-life-decadereport/Water-for-Life-Decade Report_WEB.pdf (accessed June 8, 2016).

UN Water. (2015b). Wastewater Management: A UN-Water Analytical Brief. Geneva, Switzerland: UN Water. Available at: www.unwater.org/publications/publications-detail/pt/c/275896/ (accessed June 8, 2016).

UN Water. (2016). GEMI Background and Objectives. Available at: www.unwater.org/GEMI (accessed June 8, 2016).

U.S. Agency for International Development (USAID) (19661968). Country Assistance Program Books, Fiscal Years 1966, 
1967, 1968. Washington, DC: U.S. Agency for International Development.

U.S. Department of Energy (U.S. DOE). (2006). Energy Demands on Water Resources: Report to Congress on the Interdependency of Energy and Water. Washington, DC: U.S. Department of Energy.

U.S. Department of Energy (U.S. DOE). (2014). The WaterEnergy Nexus: Challenges and Opportunities. Washington, DC: U.S. Department of Energy.

Van Houweling, E. (2015). Gendered water spaces: A study of the transition from wells to handpumps in Mozambique. Gend. Place Culut. 22, 1391.

Venkateswara Rao, P., Baral, S.S., Dey, R., and Mutnuri, S. (2010). Biogas generation potential by anaerobic digestion for sustainable energy development in India. Renew. Sustain. Energy Rev. 14, 2086.

Verbyla, M.A, Naughton, C.C., Vernaza-Hernandez, V., Feldman, A., Wells, E.C., Trotz, M.A., and Mihelcic, J.R. (2014). Using social media to create a global community of sustainability-engaged students. Proceedings of 3rd Annual American Society for Engineering Education, International Forum. Indianapolis, IN.

Verbyla, M.E., and Mihelcic, J.R. (2015). A review of virus removal in wastewater treatment pond systems. Water Res. 71, 107.

Verbyla, M.W., Oakley, S.M., Lizima, L.A., Zhang, J., Iriarte, M., Tejada-Martinez, A.E., and Mihelcic, J.R. (2013a). Taenia eggs in a stabilization pond system with poor hydraulics: Concern for human cysticercosis? Water Sci. Technol. 68, 2698.

Verbyla, M.E., Oakley, S.M., and Mihelcic, J.R. (2013b). Wastewater infrastructure for small cities in an urbanizing world: Integrating the protection of human health and the environment with resource recovery and food security. Environ. Sci. Technol. 47, 3598.

Vergara, W., Deeb, A., Leino, I., Kitoh, A., and Escobar, M. (2011). Assessment of the Impacts of Climate Change on Mountain Hydrology: Development of a Methodology through a Case Study in the Andes of Peru. Washington, DC: World Bank Publications. Available at: https://openknowledge.worldbank .org/handle/10986/2278 (accessed June 8, 2016).

Vernaza-Hernadez, V., and Feldman, A. (2016). The value of international experiences in the development of engineering science graduate students' global competency. In: J. Lavonen, K. Juuti, J. Lampiselka, A. Uitto, and K. Hahl, Eds., Science Education Research: Engaging Learners for a Sustainable Future, Part 12: Cultural, social and gender issues in science and technology education. Helsinki, Finland: European Science Education Research Association. ISBN 978-951-511541-6, pp. 1871-1879.

Wan Alwi, S.R., Manan, Z.A., Klemeš, J.J., and Huisingh, D. (2014). Sustainability engineering for the future. J. Clean. Prod. 71, 1.

2030 Water Resources Group. (2009). Charting Our Water Future: Economic Frameworks to Inform Decision Making. Munich, Germany: McKinsey and Company. Available at: www.mckinsey.com/client_service/sustainability/latest_ thinking/charting_our_water_future (accessed June 8, 2016).

Weinzierl, T., and Schilling, J. (2013). On demand, development and dependence: A review of current and future implications of socioeconomic changes for integrated water resource management in the Okavango catchment of Southern Africa. Land 2, 60.

Welker, M. (2012). The Green Revolution's ghost: Unruly subjects of participatory development in rural Indonesia. Am. Ethnol. 39, 389.
Wells, E.C., Davis-Salazar, K.L., and Moreno Cortés, J.E. (2014). Scale as a key factor for sustainable water management in northwest Honduras. J. Ecol. Anthropol. 17, 1.

Wells, E.C., Zarger, R.K., Whiteford, L.M., Mihelcic, J.R., Koenig, E.S., and Cairns, M.R. (2016). The impacts of tourism development on perceptions and practices of sustainable wastewater management on the Placencia Peninsula, Belize. J. Clean. Prod. 111, 430.

Whiteford, L.M., Cairns, M.R., Zarger, R.K., and Larsen, G. (2016). Water, Environment, and Health: The political ecology of water. In M. Singer, Ed., A Companion to Anthropology of Environmental Health. New York: Wiley-Blackwell, pp. 219-235.

Whiteford, L.M., and Vindrola Padros, C. (2015a). Community Participatory Involvement: A Sustainable Model for Global Public Health. Walnut Creek, CA: Left Coast Press.

Whiteford, L.M., and Vindrola Padros, C. (2015b). Water, health and social inequality. In J.D. Wright, Ed., International Encyclopedia of the Social and Behavioral Science. Kidlington, Oxford, United Kingdom: Elsevier, Ltd.

Whiteford, L.M., and Whiteford, S. (2005). Globalization, Water and Health: Resources in Times of Scarcity. Santa Fe, NM: School of American Research Press.

Widmann, J., and Vanasupa, L. (2008). Work in progressAttaining and measuring global competency for engineering graduates. Proceedings of the 38th ASEE/IEEE Frontiers in Education Conference, Saratoga Springs, NY: Institute of Electrical and Electronics Engineers. p. 11.

Wigginton, K.R., Ye, Y., and Ellenberg, R.M. (2015). Emerging investigators series: The source and fate of pandemic viruses in the urban water cycle. Environ. Sci. Water Res. Technol. 1, 735. Wilbur, P. (2014). An Evaluation of the Use of Composting Latrines and the Perceptions of Excrement in Ngäbe Communities in Panama. Master of Science in Environmental Engineering Thesis, University of South Florida. Available at: http:// scholarcommons.usf.edu/etd/5331/ (accessed June 8, 2016).

Winz, I., Brierley, G., and Trowsdale, S. (2009). The use of system dynamics simulation in water resources management. Water Resour. Manag. 23, 1301.

World Bank. (2012). Inclusive Green Growth: The Pathway to Sustainable Development. Washington, DC: 2012 International Bank for Reconstruction and Development/International Development Association, The World Bank. Available at: https://sustainabledevelopment.un.org/index.php?page = view \&type $=400 \& n r=690 \&$ menu $=35$ (accessed June 8, 2016).

World Economic Forum. (2011). Water Security: The WaterEnergy- Food-Climate Nexus. Washington, DC: Island Press. Available at: www.weforum.org/reports/water-securitywater-energy-food-climate-nexus (accessed June 8, 2016).

World Energy Council. (2010). Water for Energy. London: World Energy Council. Available at: www.worldenergy.org/publications/ 2010/water-for-energy-2010/ (accessed June 8, 2016).

World Health Organization (WHO). (2008). Global Burden of Disease: 2004 Update. Geneva, Switzerland: WHO. Available at: www.who.int/healthinfo/global_burden_disease/2004_ report_update/en/ (accessed June 8, 2016).

World Health Organization (WHO). (2014). Quantitative Risk Assessment of the Effects of Climate Change on Selected Causes of Death, 2030s and 2050s. S. Hales, S. Kovats, S. Lloyd, and D. Campbell-Lendrum, Eds. Available at: www.who.int/ globalchange/publications/quantitative-risk-assessment/en/ (accessed June 8, 2016).

World Health Organization (WHO). (2015). Health Topics: Air Pollution. WHO. Available at: www.who.int/topics/air_ pollution/en/ (accessed June 8, 2016). 
World Health Organization (WHO) and United Nations Children's Fund (UNICEF). (2014). Progress on Drinking Water and Sanitation: 2014 Update. Geneva, Switzerland: WHO and UNICEF. Available at: www.wssinfo.org/fileadmin/ user_upload/resources/JMP_report_2014_webEng.pdf (accessed June 8, 2016).

World Resources Institute (WRI) in Collaboration with United Nations Development Programme, United Nations Environment Programme, and World Bank. (2005). World Resources 2005: The Wealth of the Poor-Managing Ecosystems to Fight Poverty. Washington, DC: WRI.

World Water Assessment Programme (WWAP). (2003). Water for People, Water for Life: The United Nations World Water Development Report. Paris, France: UNESCO and Berghahn Books. Available at: www.unesco.org/new/en/naturalsciences/environment/water/wwap/wwdr/wwdr1-2003/ (accessed June 8, 2016).

World Water Assessment Programme (WWAP). (2012). Managing Water Under Uncertainty and Risk. The United Nations World Water Development Report 4, Volume 1. Paris, France: UNESCO. Available at: www.unesco.org/new/en/naturalsciences/environment/water/wwap/wwdr/wwdr4-2012/ (accessed June 8, 2016).
World Water Assessment Programme (WWAP). (2014). The United Nations World Water Development Report 2014: Water and Energy. Paris, France: UNESCO. Available at: www.unesco.org/new/en/natural-sciences/environment/ water/wwap/wwdr/2014-water-and-energy/ (accessed June 8, 2016).

Wright Wendel, H.E., Downs, J.A., and Mihelcic, J.R. (2011). Assessing equitable access to urban green space: The role of engineered water infrastructure. Environ. Sci. Technol. 45, 728.

Wright Wendel, H.E., Zarger, R.K., and Mihelcic, J.R. (2012). Accessibility and usability: Green space preferences, perceptions, and barriers in a rapidly urbanizing city in Latin America. Landsc. Urban Plan. 107, 272.

Zhuang, Y.L. (2014). A System Dynamics Approach to Integrated Water and Energy Resources Management. Ph.D. in Environmental Engineering Dissertation, University of South Florida. Available at: http://scholarcommons.usf.edu/etd/ 5164/ (accessed June 8, 2016).

Zhuang, Y.L., and Zhang, Q. (2015). Exploring Water-Energy Nexus towards Integrated Water and Energy Management. Paper presented at the 33rd International Conference of the System Dynamics Society. Cambridge, MA, July 19-23. 